\title{
Additions to the diversity of rare or overlooked lichens and lichenicolous fungi in Ukrainian Carpathians
}

\author{
JAN VONDRÁK \\ ZDENĚK PALICE \\ ALEXANDER KHODOSOVTSEV \\ SERGIY POSTOYALKIN
}

ВОНДРАК Я., ПАЛІЦЕ З., ХОДОСОВЦЕВ А., ПОСТОЯЛКІН С., 2010: Доповнення до різноманіття рідкісних або маловідомих лишайників та ліхенофільних грибів Українських Карпат. Чорноморськ. бот. ж., Т. 6, №1: 6-34.

\begin{abstract}
Наводяться дані щодо 103 рідкісних, маловідомих та спорадично поширених видів лишайників та ліхенофільних грибів з Українських Карпат. Вперше для України виявлено 29 видів ліхенізованих, три види ліхенофільних та один альгофільний гриб: Absconditella sphagnorum, Adelolecia kolaensis, Arthonia muscigena, Arthrorhaphis aeruginosa, Biatora albohyalina, Brodoa atrofusca, Bryodina rhypariza, Calicium pinastri, Caloplaca fuscorufa, C. isidiigera, Carbonea invadens, Catillaria croatica, Cryptodiscus gloeocapsa, Cystocoleus ebeneus, Epigloea medioincrassata, Gyalidea fritzei, Lecidea pullata, Lecidella patavina, Melaspilea granitophila, Micarea turfosa, Monodictys epilepraria, Opegrapha corticola, Phaeographis inusta, Polyblastia schaereriana, Protothelenella sphinctrinoides, Psilolechia clavulifera, Pycnora leucococca, Rinodina orculata, Sclerococcum griseisporodochium, Thelocarpon robustum auct. brit., non Eitner, Trapeliopsis glaucolepidea and Vezdaea stipitata. Усі гербарні зразки під назвою Brodoa intestiniformis, які були зібрані з території Українських Карпат відносятьсяся до $B$. atrofusca. Повідомлення щодо зростання Chaenotheca cinerea на території Українських Карпат є недостовірними. Наводяться перші реальні місцезнаходження Caloplaca conversa, Chaenotheca cinerea та Lecidea sphaerella для України. Multiclavula mucida та Schaereria fuscocinerea у зведеннях щодо лишайників Східних Карпат та України відсутні, однак повідомлення про ці види знайдені в українських та чеських джерелах. Pertusaria ophthalmiza був невірно наведений для України під назвою P. multipuncta i тому повинен бути виключеним із чекліста лишайників України. Phaeographis dendritica та Biatora meiocarpoides також виключаються із списку українських лишайників, тому що перший був некоректно наведений 3 Українських Карпат, а другий є синонімом до Micarea lithinella.
\end{abstract}

Ключові слова: Українські Карпати, Украӥна, рідкісні лишайники, Thelocarроп robustum

Vondrák J., Palice Z., Khodosovtsev A., Postoyalkin S., 2010: Additions to the diversity of rare or overlooked lichens and lichenicolous fungi in Ukrainian Carpathians. Chornomors'k. bot. z., Vol. 6, №1: 6-34.

Data on 103 rare or overlooked lichenized, lichenicolous and lichen-allied fungi from Ukrainian Carpathians are provided. Among them, 29 lichen-forming fungi, three lichenicolous fungi and one (facultatively lichenicolous) algicolous fungus are new to Ukraine: Absconditella sphagnorum, Adelolecia kolaensis, Arthonia muscigena, Arthrorhaphis aeruginosa, Biatora albohyalina, Brodoa atrofusca, Bryodina rhypariza, Calicium pinastri, Caloplaca fuscorufa, C. isidiigera, Carbonea invadens, Catillaria croatica, Cryptodiscus gloeocapsa, Cystocoleus ebeneus, Epigloea medioincrassata, Gyalidea fritzei, Lecidea pullata, Lecidella patavina, Melaspilea granitophila, Micarea turfosa, Monodictys epilepraria, Opegrapha corticola, Phaeographis inusta, Polyblastia schaereriana, Protothelenella sphinctrinoides, Psilolechia clavulifera, Pycnora

(C) J. Vondrák, Z. Palice, A. Khodosovtsev, S. Postoyalkin Чорноморськ. бот. ж., Т. 6, №1: 6-34. 
leucococca, Rinodina orculata, Sclerococcum griseisporodochium, Thelocarpon robustum auct. brit., non Eitner, Trapeliopsis glaucolepidea and Vezdaea stipitata. There is no reliable/confirmed record of Brodoa intestiniformis from Ukrainian Carpathians; all herbarium samples named as such proved to be $B$. atrofusca or were misidentified. All references to Chaenotheca cinerea in checklists which consider Ukraine are erroneous or very dubious, thus our record is the first reliable for Ukraine, as are our collections of Caloplaca conversa and Lecidea sphaerella. Although Multiclavula mucida and Schaereria fuscocinerea are absent from lichen checklists of Eastern Carpathians and Ukraine, they have been reported from the territory in previous published Czech or Ukrainian papers. Pertusaria ophthalmiza was recorded from Ukraine, incorrectly as P. multipuncta, but the presence of true P. multipuncta (Turner) Nyl. (non auct.) is uncertain in Ukraine. Phaeographis dendritica and Biatora meiocarpoides should be excluded from upcoming lists of Ukrainian lichens; the former is incorrectly reported from Ukrainian Carpathians and the latter is a synonym of Micarea lithinella.

Keywords: Ukrainian Carpathians, Ukraine, threatened species, Thelocarpon robustum

ВОНДРАК Я., ПАЛИЦЕ З., ХОДОСОВЦЕВ А., ПОСТОЯЛКИН С., 2010: Дополнение к разнообразию редких или малоизвестных лишайников и лихенофильных грибов Украинских Карпат. Чорноморск. бот. ж., Т. 6, №1: 6-34.

\begin{abstract}
Приводятся данные о 103 редких, малоизвестных и спорадично встречающихся видов лишайников и лихенофильных грибов с Украинских Карпат. Впервые для Украины выявлено 29 видов лихенизированных, три вида лихенофильних и один альгофильный гриб: Absconditella sphagnorum, Adelolecia kolaensis, Arthonia muscigena, Arthrorhaphis aeruginosa, Biatora albohyalina, Brodoa atrofusca, Bryodina rhypariza, Calicium pinastri, Caloplaca fuscorufa, C. isidiigera, Carbonea invadens, Catillaria croatica, Cryptodiscus gloeocapsa, Cystocoleus ebeneus, Epigloea medioincrassata, Gyalidea fritzei, Lecidea pullata, Lecidella patavina, Melaspilea granitophila, Micarea turfosa, Monodictys epilepraria, Opegrapha corticola, Phaeographis inusta, Polyblastia schaereriana, Protothelenella sphinctrinoides, Psilolechia clavulifera, Pycnora leucococca, Rinodina orculata, Sclerococcum griseisporodochium, Thelocarpon robustum auct. brit., non Eitner, Trapeliopsis glaucolepidea и Vezdaea stipitata. Все гербарне образцы, хранящиеся под названием Brodoa intestiniformis и собранные в Украинских Карпатах, относяться к B. atrofusca. Сообщения о произрастании Chaenotheca cinerea в Украинских Карпатах являються ошибочными или недостоверными. Приводяться первые реальные локалитеты Caloplaca conversa, Chaenotheca cinerea и Lecidea sphaerella для Украини. Multiclavula mucida и Schaereria fuscocinerea отсутствуют в сводках о лишайниках Восточных Карпат и Украины, однако найдены в в украинских и чешских литературных источниках. Pertusaria ophthalmiza был неверно определен для Украины под названием P. multipuncta, потому он должен быть исключен из чеклиста лишайников Украины. Phaeographis dendritica и Biatora meiocarpoides также исключаються из списка украинских лишайников, в святи с тем что первый был некорректно приведен для Украинских Карпат, а второй является синонимом к Micarea lithinella.
\end{abstract}

Ключевые слова: Украинские Kaрпаты, Украина, редкие виды, Thelocarpon robustum

Our contribution follows the tradition of lichen biodiversity investigations in Eastern Carpathians by Czech lichenologists that flourished in the second and third decades of the 20th century [e.g. SUZA, 1925 a, c, 1926, 1927, 1934, 1936; NÁDVORNíK, 1932; SERVít, NÁdVORNíK, 1932; 1936; SERVÍT, ČERNOHORSKÝ, 1935; HiLITZER, 1940] and by Ukrainian lichenologists who continued this work [е.g. МАКАРЕВич, 1947, 1950, 1952 a, б; 1954 a, б, 1955, 1963; ОкСНЕР, 1956, 1968]. The results of these papers were summarized in МАКАРЕВИЧ и др. [1982].

The Carpathians represent a lichen biodiversity hot-spot within the Ukrainian territory; the presence, for example, of epiphytic lichens with a strongly oceanic distribution in Europe is unique. SUZA [1934] exemplified this phenomenon by reference to Pannaria conoplea 
(Ach.) Bory, P. rubiginosa (Ach.) Bory and Cetraria oakesiana Tuck. [syn. Usnocetraria oakesiana (Tuck.) M.J. Lai \& J.C. Wei]. All three species are absent from the Western Carpathians, their closest localities being in the Southern Carpathians and in the Alps. Other remarkable examples with distinct oceanic tendencies (i.e. demanding high and stable humidity), some of them known only from historical records, are Byssoloma subdiscordans (Nyl.) P. James [SUZA, 1923, as B. leucoblepharum; SuZA, 1936, as B. tricholomum], Pyxine sorediata (Ach.) Mont. [LYNGE, 1935; NÁDVORNí, 1947, both as Physcia endochrysoides], Porina hibernica P. James \& Swinscow [COPPINS et al., 1998; 2005 as Zamenhofia hibernica], Arthonia ilicina Taylor, Eopyrenula avellanae Coppins, Lecanora farinaria Hook. [COPPINS et al., 2005], Thelotrema suecicum (H. Magn.) P. James [PURVIS et al., 1995; this paper], Opegrapha corticola Coppins \& P. James and Phaeographis inusta (Ach.) Müll. Arg. [this paper]. High precipitation may be responsible for these occurrences; in Uzhgorod, situated in lowland at SW foot of Eastern Carpathians, it is high $(773 \mathrm{~mm})$ and rather stable throughout the year [LIETH et al., 1999].

\section{Materials and Methods}

The records presented here are based on extensive collecting of lichen material during excursions in October 1994, September 1995, June-July 1997 (Z. Palice), June-July 2007 (J. Vondrák) and targeted research in 2005-2006 (A. Khodosovtsev and S. Postoyalkin). The mountain ranges of Chornohora, Svidovets, Horgany, Kuziysky and Uholsky massifs were visited. Individual records from these trips have already been published [BREUSS, 1998a,b; PrintZen, PALICE, 1999; PrintZEN et al., 1999; CZARNOTA, 2004, 2007; ПОСтОЯЛКIH, 2006; ХодосовцЕв, ПостоялКИН, 2007; DiEDERICH et al., 2008; VONDRÁK et al., 2008], and descriptions of three new taxa were in part based on samples from these excursions, i.e. Verrucaria phloephila Breuss, Verrucaria viridigrana Breuss and Caloplaca subalpina Vondrák, Šoun et Palice.

Vouchers to the records are deposited in CBFS (coll. J. Vondrák), PRA (coll. Z. Palice) and KHER (coll. A. Khodosovtsev and S. Postoyalkin). The nomenclature of geomorphologic regions of Ukraine follows KONDRATYUK et al. [2003]. Geographical names are transcribed from Cyrillic according to АНДРІєнКО та ін. [1999]. Species new to Ukraine are indicated by an asterisk; lichenicolous and lichen-allied fungi are listed separately.

In connection with this work, the second author revised some unpublished herbarium specimens (BRA, PRM) collected in the territory of the present Ukrainian Carpathians, particularly by the Czech lichenologists Alfred Hilitzer, Josef Nádvorník and Jindřich Suza. Label data of these specimens are cited in the original language.

\section{Lichen-forming fungi}

\section{ABSCONDitella annexa (Arnold) Vězda}

Collecting site: Chornohora Mts: Mt Hoverla, alt. 1900-2000 m, over decaying liverworts (Gymnomitrion sp.) in sandstone rock crevices, 15.9.1995, B. Gruna, Z. Palice (PRA).

At approximately the same locality, the species was previously collected by SUZA [1936, as Gyalecta annexa].

\section{AbSCONDitella lignicola Vězdạ \& Pišút}

Collecting sites: Chornohora Mts: Lazeshchina valley, c. $3 \mathrm{~km}$ upstream from Lazeshchina village, on rotten wood, alt. $900 \mathrm{~m}, 14.9 .1995$, B. Gruna, Z. Palice (PRA); Svidovets Mts: valley of "Svidovetsky potik" brook, on wood, alt. 700-900 m, 29.6.1997, Z. Palice 13316 (PRA); Svidovets Mts: valley of Stanislava brook, at base of Acer pseudoplatanus, alt. $1150 \mathrm{~m}, 30.6 .1997$, Z. Palice (PRA).

The lichen was recently reported from Uzhansky reserve in Eastern Beskydy [KONDRATYUK, COPPINS, 2000; COPPINS et al., 2005]. 


\section{*ABSCONDitella sphagnorum Vězda \& Poelt}

Collecting sites: Chornohora Mts: - NW slopes of Mt Chornohora, c. $2 \mathrm{~km}$ of summit, over Sphagnum hummocks among boulders, alt. c. $1800 \mathrm{~m}, 26.6 .1997$, Z. Palice (PRA); Horgany Mts: Mt Bratkovs'ka, on Sphagnum above timber-line, alt. c. 1750 m, 2.7.1997, Z. Palice (PRA); Nadvirna, Stara Hutya, Mt Sivulya in Horgany Mts, alt. 1700-1800 m, over Sphagnum in scree at timber line, 2.7.2007, J. Vondrák (CBFS JV6749, 6780).

Similar to A. delutula, but usually grows on Sphagnum cushions (more rarely on other bryophytes, peat and wood), and has somewhat larger pinkish apothecia, 0,2-0,4 $\mathrm{mm}$ in diam. The world distribution is summarized in CZARNOTA, KUKWA [2008].

\section{*ADELOLECIA kolaensis (Nyl.) Hertel \& Rambold}

Collecting site: Chornohora Mts: Mt. Hoverla, on shaded sandstone overhanging rock, alt. 1950-2000 m, 27.6.1997, Z. Palice 12047 (PRA).

It is probably a circumpolar holarctic lichen with a preference for a cool oceanic climate. In the Alps and Western Carpatians, it is known from an elevation of 1400-2200 m. Similar to $A$. pilati, but the $\mathrm{K}+$ purple anthraquinone (7-chloroemodin) is absent in the exciple, and the ascospores are narrowly ellipsoid to oblong. It may be confused for a Catillaria s. lat. because 1-septate ascospores are often present [HERTEL, RAMBOLD, 1995].

Agonimia allobata (Stizenb.) P. James

Collecting sites: Chornohora Mts: Uholsky massive, Mala Uhol'ka, Voyevuts'ke, way to polonyna Menchul, at the base of Fagus, alt. $950 \mathrm{~m}, 24.07 .2005$, A. Khodosovtsev, S. Postoyalkin (KHER).

Previously known only from Uzhansky nature reserve in Eastern Beskydy [KONDRATYUK, COPPINS, 2000] and the lowland plain of Ukraine [КОНДРАТюК, БЛЮМ, 1985].

AgONIMIA globulifera M. Brand \& Diederich

Collecting site: Marmaroshy Mts: Rachiv, protected area Kuziy (limestone gorge in valley of brook influent to river Tisza), on sun-exposed siliceous / calcareous cliff Sokoline berdo (Falcon rock), over bryophytes on lime-rich rock, 9.7.2007, J. Vondrák (CBFS JV6792, 7064).

Previously collected in Ukraine from the Crimean Mts [ХОдосовцЕВ, 2004], but new to Ukrainian Carpathians.

Agonimia repleta Czarnota \& Coppins

Collecting site: Svidovets Mts: valley of Stanislava brook, on bark of Fagus, alt. c. 1200 m, 30.6.1997, Z. Palice 12931 (PRA).

A recently described species [CZARNOTA, COPPINS, 2000] based on the material from Poland and Ukraine (Mt Ceremkha in Eastern Beskydy). Reminiscent of diminutive $A$. tristicula, but the thallus is adpressed; the perithecia contain 8 ascospores that fit the size range of A. allobata. Furthermore, the perithecia of Agonimia repleta are black with a rough surface, while in $A$. allobata they are more brownish and smooth.

Agonimia tristicula (Nyl.) Zahlbr.

Collecting site: Horgany Mts, Nadvirna, Stara Hutya, forest above village along river Sol. Bystritsa and brook Vel. Kuzminets, on bark of Fagus sylvatica, 1.7.2007, J. Vondrák (CBFS JV6806).

Although known to occur epiphytically [WIRTH, 1995; ORANGE, PURVIS, 2009], we consider this species to mainly inhabit mosses or plant debris on base-rich rocks and soils; thus the richly fertile collection from a beech bark in an area without any lime-rich outcrops is 
unusual for us. The species has already been recorded several times on bark in Ukrainian Carpathians [COPPINS at al., 2005; ПОСТОЯЛКІн, 2006].

In Ukraine, the species was also collected in Crimea [COPPINS et al., 2001; ХодОСОВЦЕВ, 2003; ХОДОСОВЦЕВ, БОГДАН, 2006], the Khmel 'nitsk region [BIELCZYК et al., 2005] and Ternopil region [СМЕРЕЧИНСЬКА, 2006].

AINOA mooreana (Carroll) Lumbsch \& I. Schmitt (Syn. Trapelia mooreana (Carroll) P. James)

Collecting site: Chornohora Mts: Mt Hoverla, on sheltered sandstone rock, alt.19502000 m, 27.6.1997, Z. Palice 13308 (PRA).

An easily recognizable pioneer species on humid acid stones, with relatively large apothecia with prominent, often flexuose margin and with gyrophoric acid restricted to excipulum and pycnidia $(\mathrm{C}+\mathrm{red})$. Distinguished by structure of excipulum from related Trapelia and Trapeliopsis [LUMBSCH et al., 2001]. In Ukrainian Carpathians, it has only once been recorded from the Chornohora Mts [SuZA, 1936, as Lecidea brujeriana].

Arthonia leucopellaea (Ach.) Almq.

Collecting sites: Chornohora Mts: Mt Pietros, old-growth forest on slope facing Lazeshchina valley, on bark of Abies, alt. c. $1300 \mathrm{~m}, 17.9 .1995$, Z. Palice 12228 (PRA, cum Opegrapha sp.); Horgany Mts, Nadvirna, Stara Huta, forest above village along river Sol. Bystrica and brook Vel. Kuzminec, on bark of Picea abies, 1.7.2007, J. Vondrák (CBFS JV7071).

In Ukraine, one old record of the species is known from the Marmaroshy Mts [REDINGER, 1937].

*ARTHONIA muscigena Th. Fr.

Collecting site: Svidovets Mts: valley of Stanislava brook, on bark at base of Picea near the brook, alt. c. $950 \mathrm{~m}, 30.6 .1997$, Z. Palice (PRA).

In Ukraine, it is otherwise only known from the Crimean Peninsula on Pinus twigs [BOGDAN, unpublished]; samples deposited in KHER.

\section{Bacidia beckhausii Körb.}

Collecting site: Chornohora Mts: Rachiv, Luhy, virgin mixed forest along upper stream of brook Hoverla below Mt Hoverla, on bark of Ulmus glabra, 8.7.2007, J. Vondrák (CBFS JV7075).

The large-celled photobiont, epinecral granules and coherent exciple hyphae distinguish this species from similar Micarea species [COPPINS, APTROOT, 2009]. It is known in Europe, Asia and North America. From Ukraine, only one recent record exists from Uzhansky nature reserve in Eastern Beskydy [KONDRATYUK, COPPINS, 2000].

\section{BACIDIA subincompta (Nyl.) Arnold}

Collecting site: Svidovets Mts: upper part of valley of Stanislava brook, on bark of Picea, alt. 1200 m, 30.6.1997, Z. Palice (PRA); Horgany Mts: Ust'-Chorna, Turbat valley, between settlements Turbat and Ust'-Turbat, on bark Alnus incana, alt. 750 m, 3.7.1997, Z. Palice 13298 (PRA); Chornohora Mts: Rachiv, Luhy, virgin mixed forest along upper stream of brook Hoverla below Mt Hoverla, on bark of Ulmus glabra, 8.7.2007, J. Vondrák (CBFS JV7076).

In Ukraine, it has rarely been collected in the Carpathians [SERVÍT, NÁDVORNÍK, 1936, as Bacidia affinis var. endoporphyrea; COРPINS et al., 1998; ПостОялКІН, ХОДОСОВЦЕВ, СУХАРЮК, 2007] and mountains in Crimea [ХОДОСОВЦЕВА, 2009]. 
Additions to the diversity of rare or overlooked lichens and lichenicolous fungi in Ukrainian Carpathians

BELONIA russula Nyl.

Collecting site: Chornohora Mts: Mt Hoverla, on shaded sandstone rock on NE-slope, alt. 1900-2000 m, 15.9.1995, B. Gruna, Z. Palice (PRA); Svidovets Mts: Rachiv, Chorna Tisza, Mt Tataruka, alt. c. $1650 \mathrm{~m}$, on acidic sandstone at timberline, 28.6.2007, J. Vondrák (CBFS JV7063).

The oldest collection (19th century) from Mt Pop Ivan Marmaroshsky was made by H. Lojka and determined by A. Zahlbruckner [SERVÍT, 1925]. All three previous collections from the Ukrainian Carpathians by H. Lojka and J. Nádvorník come from Chornohora Massif [SERVÍT, NÁDVORNÍK, 1936; VĚZDA, 1959].

\section{*BIATORA albohyalina (Nyl.) Bagl. \& Carestia}

Collecting site: Chornohora Mts: Rachiv, Luhy, virgin mixed forest along upper stream of brook Hoverla below Mt Hoverla, on bark of Ulmus glabra, 8.7.2007, J. Vondrák (CBFS JV7082).

Morphologically similar to Lecidea meiocarpa or shaded forms of Biatora helvola, but distinguished by predominantly simple ascospores that usually do not exceed $3 \mu \mathrm{m}$ in width, exciple anatomy and long acicular conidia (c. $25-50 \times 1,5-2 \mu \mathrm{m}$ ). Conidia often protrude from pycnidia as white caps. For a detailed description see PRINTZEN and TøNSBERG [2000]. It seems to have temperate to arctic distribution [KUKWA et al., 2008]. Phylogenetic tree based on molecular data (ITS rDNA) in SPRIBILLE et al. [2009] indicates that the species should be placed in the genus Lecania.

BIATORA ocelliformis (Nyl.) Arnold

Collecting site: Chornohora Mts: Rachiv, Luhy, virgin mixed forest along upper stream of brook Hoverla below Mt Hoverla, on bark of Ulmus glabra, 8.7.2007, J. Vondrák (CBFS JV7084); Marmar.: Luhy, alt. 750 m, 1931, J. Nádvorník (PRM-784862, sub Lecidea atroviridis $f$. ocelliformis).

In Ukraine, it was only recently reported from the Carpathians [COPPINS et al., 1998; PRINTZEN, PALICE, 1999; KONDRATYUK, COPPINS, 2000].

BIATORIDIUM monasteriense J. Lahm ex Körb.

Collecting sites: Svidovets Mts: valley of Stanislava brook, on bark of Acer pseudoplatanus, alt. c. 950 m, 30.6.1997, Z. Palice 13288 (PRA); Marmaroshy Mts: Rachiv, protected area Kuziy (limestone gorge in valley of brook influent to river Tisza), on bark of Ulmus glabra, 9.7.2007, J. Vondrák (CBFS JV6799).

In the Ukrainian checklist [KONDRATYUK et al., 1998], it is mentioned only from Crimea, but it has been recorded from Mt Tempa near Trebushany in Ukrainian Carpathians [SUZA, 1927]. Recently it was reported from Stuzhytzia and Uzhansky nature reserves [COPPINS et al., 1998; KONDRATYUK, COPPINS, 2000], and it has also been recorded in the Khmel`nitsk region [BIELCZYK et al., 2005].

*BRODOA atrofusca (Schaer.) Goward

Collecting sites: Čorná Hora, Turkul, 31.7.1934, A. Hilitzer (PRM-836976); in alpe Turkul, in rupibus arenaceis c. 1850-1930 m, 8.1935, J. Suza (PRM-636184); Chornohora Mts: Mt Turkul - on N-NE exposed sandstone rock just below the summit, alt. c. $1900 \mathrm{~m}$, 27.6.1997, Z. Palice (PRA); Črná Hora, Tomnatek - u Trianglu, 30.7.1934, A. Hilitzer (PRM-836973); Čorná Hora, pod vrcholem, 2.7.1934, A. Hilitzer (PRM-836974).

$B$. atrofusca differs from B. intestiniformis (Vill.) Goward by its thicker thallus, absence of flattened secondary lobes and chemistry: physodic acid $(\mathrm{KC}+$ red, UV+ bluewhite) is absent in B. intestiniformis [KROG, 1974]. The species is distributed in the alpine and subalpine zone in Europe, and is common mainly in central European Mts (the Alps), but also in southern European mountains and Scandinavia [KROG, 1974]. Several records exist from the Tatry Mts in Western Carpathians [LISICKÁ, 2005]. 
Most of the herbarium specimens named Parmelia encausta (Sm.) Nyl. (syn. Brodoa intestiniformis) and published by HILITZER [1940] and SUZA [1936] from Transcarpathian Ukraine (Chornohora Mts), as well as our recent collection, belong to Brodoa atrofusca. The voucher specimen of T. Sulma published as Parmelia encausta var. intestiniformis [SULMA, 1933] is not present in UGDA herbarium (M. Kukwa, in litt.) but another collection by him from Ukraine: Mt Strymba (Chyvchyno-Grynyavskie Mts) is misidentified (mixture of Parmelia saxatilis (L.) Ach., Xanthoparmelia loxodes (Nyl.) O. Blanco et al. and a thallus belonging most probably to some other Xanthoparmelia; M. KUKWA, in litt.). One of the four Hilitzer's collections from Ukrainian Carpathians appeared to belong to Physcia caesia (Hoffm.) Hampe ex Fürnr. (det. R. Moberg, see the specimen of Lecidella patavina below). The non-specified record by HRUBY [1925] is uncertain. The general report on distribution of Brodoa intestiniformis in Ukraine by УРБАНАВИЧЮС [2001] is apparently based on literature sources and not on examined specimens (G. URBANAVICHUS, in litt.); consequently, to date, no reliable/confirmed record of $B$. intestiniformis exists from the Ukrainian Carpathians.

*BRYODINA rhypariza (Nyl.) Hafellner (BRA).

Collecting site: Chornohora Mts: Tomnatek, Čorná Hora, 30.7.1934, A. Hilitzer

The species belongs to a recently distinguished genus Bryodina Hafellner that was segregated from similarly looking Bryonora Poelt [HAFELLNER, AFELLNER, TÜRK, 2001] on the basis of previously outlined differences proposed by POELT and OBERMAYER [1991] who delimited these taxa on infrageneric level. Both genera share the dark lecanorine apothecia and a preference for growing on bryophytes at high elevations; the ability to produce norstictic acid is also common for members of both genera. Bryodina is primarily distinguished from Bryonora by its distinctly separated hypothecium and excipulum and by thin-walled ascospores. Bryodina rhypariza possess a distinct crustose thallus that tends to be squamulose, large lecanorine apothecia (up to $4 \mathrm{~mm}$ in diam.) and large, 1-celled hyaline ascospores $(17-27 \times 4-7 \mu \mathrm{m})$. This rare arctic-alpine lichen is known from highest European ranges and Scandinavia [POELT, 1983], Himalayas [POELt, OBERMAYER, 1991], and arctic Russia and Canada [e.g. ZHURBENKO, 1996; FRYDAY, 2000].

\section{*CALICIUM pinastri Tibell}

Collecting site: Chornohora Mts: Nadvirna, Lazeshchina, forested slopes below Mt Hoverla, on bark of Larix decidua, 6.7.2007, J. Vondrák (CBFS JV7070).

This recently described lichen [TIBELL, 1999] differs from C. parvum Tibell by its cylindrical asci, from $C$. glaucellum Ach. by its smaller apothecia and lacking pruina, and from C. abietinum Pers. by its shining black stalk and smaller $(9,5-13,5 \times 5,0-6,5 \mu \mathrm{m})$ ascospores. It is known from Finland, Germany, Czech Republic [TIBELL, 1999], Sweden [JONSSON, 2003], Russia [HERMANSSON, PystinA, 2004], Estonia [JÜRIAdO et al., 2000], Slovakia [PALICE et al., 2006], Poland [ŚliwA, KuKWA, 2008] and Switzerland [DIETRICH, BÜRGI-MEYER, 2008].

CAlOPLACA chrysodeta (Vain. ex Räsänen) Dombr.

Collecting site: Chornohora Mts: Rachiv, Luhy, virgin mixed forest along upper stream of brook Hoverla below Mt Hoverla, on bark of Acer pseudoplatanus, 8.7.2007, J. Vondrák (CBFS JV6759).

The species is considered saxicolous, growing below overhangs of calcareous or baserich siliceous rocks; its epiphytic occurrences are rare [VONDRÁK et al., 2007a] and these forms have been treated as a separate species (as C. borreri J.R. Laundon) [FLETCHER, LAUNDON, 2009]. It is mentioned in Ukrainian and Eastern Carpathian checklists as occurring in Ukrainian Carpathians [KONDRATYUK et al., 1998; 2003], but without any original references; however, it was recently recorded on calciferous rocks in the area [ХОДОСОВЦЕВ, 
Additions to the diversity of rare or overlooked lichens and lichenicolous fungi in Ukrainian Carpathians

Постоялкин, 2007]. It is also known from Crimea [KONDRATYUK et al., 1998; ХОДОСОВЦЕВ, 2003; ХОДОСОВЦЕВ, БОГДАН, 2005, 2006], the Khmel`nitsk region (Podil`s 'ki Tovtry national park) [BIELCZYK et al., 2005] and the Ternopil region (Medobory natural reserve) [СМЕРЕЧИНСЬКА, 2006].

CaloplaCa conversa (Kremp.) Jatta

Collecting site: Svidovets Mts: glacial cirque in NE slope below Mt Bliznitsa, alt. c. $1500 \mathrm{~m}, 48^{\circ} 14^{\prime} 21^{\prime \prime} \mathrm{N}, 2^{\circ} 14^{\prime} \mathrm{E}$, on base-rich schist and sandstone, 29.6.2007, J. Vondrák (CBFS JV6203, sub Caloplaca conciliascens).

Our specimen fits well with the morphology and ecology of the type material from the Alps (Bavaria, Oberstdorf im Allgäu, alt. 1800 m, 1859, Rehm, M-0012425!). The species has a dark-grey thallus with small apothecia (up to $0,5 \mathrm{~mm}$ in diam.) immersed in thallus or low and widely adpressed, with blackish margin and dark rust red (to almost black) disc. The identity of a similar C. conciliascens (Nyl.) Zahlbr. described also from the Alps (Tyrolia; Rottenkogel) is unclear to us, but it may be conspecific with $C$. conversa.

In Ukraine, $C$. conversa was reported from Crimea [WAINIO, 1899]. We have also collected samples from the Crimean populations but they have a different ecology (occur in sub-mediterranean zone) and belong to an unnamed related species (our unpublished molecular data). C. conversa is new to Ukrainian Carpathians.

CALOPLACA aff. crenularia (With.) J.R. Laundon

Collecting site: Svidovets Mts: at glacial lake at bottom of glacial cirque in N slope, alt. c. $1300 \mathrm{~m}, 48^{\circ} 15^{\prime} 41^{\prime \prime} \mathrm{N}, 24^{\circ} 13^{\prime} 22^{\prime \prime} \mathrm{E}$, on sun-exposed base-rich sandstone boulders, close to water, 28.6.2007, J. Vondrák (CBFS JV6198).

Caloplaca crenularia is known only from four historical localities in the western part of Ukrainian Carpathians [SERVÍT, NÁDVORNÍK, 1932, as Caloplaca festiva]. It is common in Crimea [КОПАЧЕВСКАЯ, 1986; ОКСНЕР, КОНДРАТЮК, 1993; ХОДОСОВЦЕВ, 2003] and rare in the lowland plain of Ukraine (Donetsk region) [ОКСНЕР, КОНДРАТЮК, 1993].

Molecular data (ITS sequence) suggest that $C$. crenularia is a heterogeneous taxon; our sample is closely related to the corticolous $C$. hungarica $\mathrm{H}$. Magn. and C. furfuracea $\mathrm{H}$. Magn. Saxicolous C. crenularia s. str. from coastal (rarely inland) areas of West and North Europe and from the Mediterranean / Submediterranean Europe is similar to our sample, but less related (our unpublished data).

*CAloplaca fuscorufa H. Magn.

Collecting site: Svidovets Mts: at glacial lake at bottom of glacial cirque in N slope, alt. c. $1300 \mathrm{~m}, 48^{\circ} 15^{\prime} 41^{\prime \prime} \mathrm{N}, 24^{\circ} 13^{\prime} 22^{\prime \prime} \mathrm{E}$, on base-rich sandstone boulders, 28.6.2007, J. Vondrák (CBFS JV6204).

Previously known only from Scandinavian mountains and Svalbard [ARUP et al., 2007], our record (confirmed by ITS molecular data) represents a very disjunct southern population. C. fuscorufa differs from the similar C. crenularia by its darker apothecia and larger ascospores with wider septa.

\section{*Caloplaca isidiigera Vězda}

Collecting site: Svidovets Mts: at glacial lake at bottom of glacial cirque in N slope, alt. c. $1300 \mathrm{~m}, 48^{\circ} 15^{\prime} 41^{\prime \prime} \mathrm{N}, 2^{\circ} 13^{\prime} 22^{\prime \prime} \mathrm{E}$, on sun-exposed base-rich sandstone boulders, 28.6.2007, J. Vondrák (CBFS JV6073).

Small globose to shortly vertically elongated isidia are diagnostic for $C$. isidiigera [VONDRÁK et al., 2008]. It is known from central Europe (Austria, Slovakia, Ukraine). Caloplaca isidiigera is a well-defined taxon, clearly distinguished both phenotypically and genotypically from sorediate/blastidiate $C$. chlorina (Flot.) Sandst. [Šoun et al., in prep.]; the concept in the new British flora [FLETCHER, LAUNDON, 2009], where both names are synonymized, is incorrect. 
CaloplaCa nivalis (Körb.) Th. Fr.

Collecting site: Svidovets Mts: Rachiv, Chorna Tisza, Mt Tataruka, alt. c. $1650 \mathrm{~m}$, on siliceous outcrop at timberline, with Carbonea invadens, 28.6.2007, J. Vondrák (CBFS JV6773).

In Ukrainian Carpathians, it was previously collected at two localities by SUZA [1926] in Chornohora Mts.

CaloplaCa obscurella (J. Lahm ex Körb.) Th. Fr.

Collecting site: Chornohora Mts: Uholsky massive, Mala Uhol'ka, near administrative house, alt. 450 m, on bark of Populus, 23.07.2005, A. Khodosovtsev, S. Postoyalkin (KHER).

In Ukraine, the species is known from its steppe [ХОДОСОВЦЕВ, 1999] and foreststeppe zones [ZELENKO, 2004; BIELCZYK et al., 2005] and Crimea [ХОДОСОВЦЕВ, РЕДЧЕНКО, 2002]. It is new to Ukrainian Carpathians.

CALOPLACA percrocata (Arnold) J. Steiner

Collecting site: Svidovets Mts: at glacial lake at bottom of glacial cirque in N slope, alt. c. $1300 \mathrm{~m}, 48^{\circ} 15^{\prime} 41^{\prime \prime} \mathrm{N}, 24^{\circ} 13^{\prime} 22^{\prime \prime} \mathrm{E}$, on sun-exposed base-rich sandstone boulders, 28.6.2007, J. Vondrák (CBFS JV6082, 6917 \& 7155).

This little known lichen was reported from Crimea by MERESCHKOWSKY [1920] but lacking locality details. It is new to Ukrainian Carpathians.

CaloplaCa polycarpa (A. Massal.) Zahlbr.

Collecting site: Marmaroshy Mts: Rachiv, protected area Kuziy (limestone gorge in valley of brook influent to river Tisza), on sun-exposed siliceous / calcareous cliff Sokoline berdo (Falcon rock), on lime-rich rock, 9.7.2007, J. Vondrák (CBFS JV6761).

In Ukraine, the species has been recorded from Crimea [КОПАЧЕВСКАЯ, 1986] and plain part of Ukraine [СМЕРЕЧИНСЬКА, 2006; ГАВРИЛЕНКО, ХОДОСОВЦЕВ, 2009].

CaloplaCA sinapisperma (Lam. \& DC.) Maheu \& A. Gillet

Collecting site: Svidovets Mts: at glacial lake at bottom of glacial cirque in N slope, alt. c. $1300 \mathrm{~m}, 48^{\circ} 15^{\prime} 41^{\prime \prime} \mathrm{N}, 24^{\circ} 13^{\prime} 22^{\prime \prime} \mathrm{E}$, over bryophytes on base-rich sandstone outcrop, 28.6.2007, J. Vondrák (CBFS JV6202).

It is a rare species in Ukraine known from three localities in the Carpathians: in Eastern Beskydy (Pol. Bukowska), Chornohora Mts (Mt Pietros) [SERvít, NÁDVORNík, 1936, as Blastenia leucoraea], and Chyvchyn-Grynyavsky Mts [МАКАРЕВИЧ, 1955, as Blastenia leucoraea], and Crimea [КОПАЧЕВСКАЯ, 1986].

CANDELARIELla efflorescens R.C. Harris \& Buck

Collecting sites: Chornohora Mts: Uholsky massive, Mala Uhol ka, Rg Hreben`, way to Chur' Mt, alt. $650 \mathrm{~m}$, on bark of Fagus sylvatica, 26.7.2005, A. Khodosovtsev, $S$. Postoyalkin (KHER); Ibid.: near administrative house, alt $410 \mathrm{~m}$, on bark of Prunus, 23.7.2005, A. Khodosovtsev, S. Postoyalkin (KHER); Ibid.: slope to Mala Uhol'ka river, Voevuts'ke, way to polonyna Menchul, alt. 1050 m, on bark of Fagus sylvatica, 24.07.2005, A. Khodosovtsev, S. Postoyalkin (KHER); Velyka Uhol'ka, way to site "polonyna Menchul", on Fraxinus, alt. 1000 m, 30.7.2006, A. Khodosovtsev, S. Postoyalkin (KHER); Ibid.: alt. 1200 m, 1.8.2006, A. Khodosovtsev, S. Postoyalkin (KHER); Velyka Uhol'ka, on Juglans regia, 4.8.2006, A. Khodosovtsev, S. Postoyalkin (KHER).

In Ukraine, the species has been found in Lviv, Kherson, Chernivets and Zhytomur regions, in Crimea [ХОДОСОВцЕВ, 2005] and in Zakarpats ka oblast region [ПостоялКІн та iн., 2007]. 
Additions to the diversity of rare or overlooked lichens and lichenicolous fungi in Ukrainian Carpathians

CANDElariella faginea Nimis, Poelt \& Puntillo

Collecting site: Chornohora Mts: Uholsky massive, Mala Uhol'ka, Rg Hreben', way to Chur' Mt, alt. 850 m, on bark of Fagus sylvatica, 26.7.2005, A. Khodosovtsev, S. Postoyalkin (KHER).

In Ukraine, it is known only from one site in Crimea [ХОДОсовцЕВ, 2005].

CANDELARIElla reflexa (Nyl.) Lettau

Collecting site: Chornohora Mts: Uholsky massive, Mala Uhol'ka, Hreben`, way to Mt Chur', alt. 650 m, 26.7.2005, A. Khodosovtsev, S. Postoyalkin (KHER).

In Ukrainian Carpathians, it was collected from the Zakarpats'ka vozvichenost' upland [SERVÍT, NÁDVORNÍK, 1936] and recently in Eastern Beskydy in nature reserves Stuzhytzia [COPPINS et al., 1998] and Uzhansky [KONDRATYUK, COPPINS, 2000]. We consider it to be a common species in the Carpathians.

*CARbonea invadens (H. Magn.) M.P. Andreev

Collecting site: Svidovets Mts: Rachiv, Chorna Tisza, Mt Tataruka, alt. c. 1650 m, on siliceous outcrop at timberline, partly lichenicolous on Lecanora, 28.6.2007, J. Vondrák (CBFS JV6774).

It was found growing together with Lecanora polytropa, but characters of the sample do not fit with either of the two Carbonea species lichenicolous on L. polytropa. The ascospores are 9-13 $\times 3-4 \mu \mathrm{m}$ in diameter with rounded apices and rarely have septa, the lower hymenium is blue-green and the hypothecium colourless. All characters agree well with the arctic species C. invadens [АНДРЕЕВ, 2003], which has only been known from its type locality in the Russian arctic.

*CATILlaRia croatica Zahlbr.

Collecting sites: Svidovets Mts: valley of Stanislava brook, on bark of Acer pseudoplatanus, alt. 1150 m, 30.6.1997, Z. Palice 12978 (PRA), det. C. Printzen; Chornohora Mts: Rachiv, Luhy, virgin mixed forest along upper stream of brook Hoverla below Mt Hoverla, on bark of Ulmus glabra, 8.7.2007, J. Vondrák (CBFS JV7074, 7077).

The species does not belong to Catillaria s.str. [PRINTZEN, 1995] and differs from other biatoroid epiphytic lichens by its sorediate thallus, 1-2 celled hyaline ascospores and negative chemical tests. It is distinguished from superficially similar Mycobilimbia epixanthoides in its preference for growing on bark (not over bryophytes), punctiform convex soralia in young parts of thalli (later confluent in extensive patches) and in ascospore septation (1-2-celled vs. 4-celled) [HAFELLNER et al., 2005]. The most comprehensive description of the species is given by HARRIS and LENDEMER [2010] who extensively studied Eastern North American material. In Europe it is a rarely collected species. Except for the Croatian type locality, it has recently been reported several times from the Alps [e.g. MRAK et al., 2004; GRONER, 2005; HAFELLNER et al., 2005]. It has also been found in the Carpathians in Romania [see MORUZI et al., 1967] and Slovakia [voucher specimen "Palice 8725" in REESE NÆSBORG et al., 2007]. The species was transferred into Lecania by KOTLOV [2004] and this view is followed by HARRIS and LENDEMER [2010]; however, based on molecular data, it is not a member of Lecania s. str. but rather belongs (together with Lecidea sphaerella Hedl. and members of Thamnolecania group) in Bilimbia s. lat. [REESE NÆSBORG et al., 2007]. The species is likely to be overlooked as it often lacks apothecia [HARRIS, LENDEMER, 2010]

CATillaria minuta (A. Massal.) Lettau

Collecting site: Marmaroshy Mts: Rachiv massive, protected area Kuziy (limestone gorge in valley of brook influent to river Tisza), on shaded limestone rock, 9.7.2007, $J$. Vondrák (CBFS JV6739). 1982].

In Ukraine, it has only been recorded from the Horgany Mts [МАКАРЕВИч и др., 
ChaenothecA cinerea (Pers.) Tibell (Syn. Chaenotheca schaereri (De Not.) Zahlbr., non Calicium schaereri sensu Nádvorník)

Collecting site: Chornohora Mts: valley of unnamed tributary to Lazeshchina brook on N slopes of Mt Pietros, on bark of Acer pseudoplatanus, alt. c. 1200 m, 17.9.1995, B. Gruna, Z. Palice (PRA, conf. L. Tibell).

This is a very rare lichen in Europe with mostly historical records [TIBELL, 1980]. From Ukraine, it was only reported from Crimea [see KONDRATYUK et al., 1998], but revison of relevant material excluded the species from the Crimean lichen biota [Титов, 1998]. The name $C h$. cinerea also appeared in recent Eastern Carpathian checklist [KONDRATYUK et al., 2003], but only with erroneous references, mostly based on Calicium schaereri sensu Nádvorník, which is a synonym of $C$. lenticulare Ach. [TiBELL et al., 2003]. Only one historical report might potentially represent true Chaenotheca cinerea [SZATALA, 1923, as Ch. trichialis var. cinerea]. However, SzATALA [1923, 1927b] evidently distinguished between Ch. cinerea (named Ch. schaereri by him) and deficiently stalk-pigmented forms of $C h$. trichialis (Ach.) Th. Fr. and his concept was very likely adopted by NÁDVORNík [1942] who clearly delimited Ch. cinerea (as Ch. schaereri) from Ch. trichialis $f$. cinerea in his key. Moreover, one of Szatala's specimens named Ch. cinerea was re-evaluated and placed under Ch. trichialis $f$. filiformis Szatala by the same author [see SzATALA, 1927b: 420] and the second specimen (Turjaremete, Studnik) was revised as Ch. trichialis by L. Tibell in 1971 (specimen L32267; see the Stockholm herbarium database: http://andor.nrm.se/fmi/xsl/ kryptos/kbo/publFindspecies.xsl?-view\&-db=kbo_svampregister\&-token.languagecode=enGB). In addition, no records of $C h$. cinerea from the present territory of Ukrainian Carpathians are mentioned by monographers of the group [KEISSLER, 1938; NÁDVORNÍK, 1942; TIBELL, 1980]; our collection is the first confirmed record from Ukrainian Carpathians as well as from Ukraine.

ChaenotheCA gracilenta (Ach.) Mattsson \& Middelb.

Collecting site: Chornohora Mts: Mt Pietros - N slopes, rests of mounatin mixed forest, on bark of Acer pseudoplatanus, alt. c. 1200 m, 17.9.1995, B. Gruna, Z. Palice (PRA); Marmaroshy Mts: Rachiv massive, protected area Kuziy (limestone gorge in valley of a tributary brook of the river Tisza), on dead hardwood bark, 9.7.2007, J. Vondrák (CBFS JV6800).

This ecologically specific, skiophilic lichen has been published only from two localities in the Ukrainian Carpathians [SzATALA, 1923, as Coniocybe gracilenta] and has been excluded from the lichen biota of Crimea [Титов, 1998]. No localities were specified by J. Nádvorník in his monograph [NÁDVORNí, 1942], nevertheless, BRA herbarium houses several unpublished collections by him from the surroundings of Rachiv, Uzhgorod and Volovets (Sinevirske ozero lake) including a specimen from Nyzhni Vorota (Polonina Runa) issued in his Caliciae exsiccati (n. 9, as Coniocybe gracilenta). It is apparently an overlooked species in suitable habitats.

ChAenotheca subroscida (Eitner) Zahlbr. (Syn. Chaenotheca phaeocephala var. subhispidula Nádv.)

Collecting site: Horgany, Ust'-Chorna: the Turbat valley, on wood of (?) Picea stump by narrow forest-railway, c. $7 \mathrm{~km} \mathrm{~N}$ of Mt Unharska, alt. c. $1100 \mathrm{~m}, 14.10 .1994$, Z. Palice 12934 (PRA).

In Ukrainian Carpathians, it is only known from Chornohora Mts - the type specimen of Ch. phaeocephala var. subhispidula Nádv. synonymized with Ch. subroscida by TIBELL [1980]. It is closely related to Ch. phaeocephala (Turner) Th. Fr., but prefers boreal forests and forms a dimorphic thallus: soredia-like granules and occasional squamules near the apothecia [TIBELL, 1980]. 
Coenogonium luteum (Dicks.) Kalb \& Lücking (Syn. Dimerella lutea (Dicks.) Trevis.)

Collecting site: Marmaroshy Mts: Rachiv massive, protected area Kuziy (limestone gorge in valley of brook influent to river Tisza), on mossy bark of old Carpinus betulus, 9.07.2007, J. Vondrák (CBFS JV6744).

It is a rare suboceanic lichen, in Ukraine only known from the Carpathians [KONDRATYUK et al., 1998]. Recently collected in Stuzhytzia and Uzhansky nature reserves in Eastern Beskydy [COPPINS et al., 1998; KONDRATYUK, COPPINS, 2000].

COLLEMA occultatum Bagl.

Collecting site: Marmaroshy Mts: Rachiv massive, protected area Kuziy (limestone gorge in valley of a tributary brook of the river Tisza), on bark of solitary Malus, 9.07.2007, $J$. Vondrák (CBFS JV6783).

In Ukraine, only one uncertain record without locality details by HRUBY [1925, as Collema quadratum] exists from the Carpathians, Marmaroshy Mts.

*Cryptodiscus gloeocapsa (Arnold) Baloch, Gilenstam \& Wedin (Syn. Bryophagus gloeocapsa Nitschke ex Arnold)

Collecting site: Chornohora Mts: Mt Hoverla, in sandstone rock crevices, alt.19002000 m, 15.9.1995, B. Gruna, Z. Palice (PRA); Ibid., 27.6.1997 (PRA).

Until recently this species has been retained in the genus Bryophagus which used to be diagnosed by its chlorococcoid Gloeocystis-like photobiont against similar Trentepohliacontaining gyalectoid genera. The genus has been further characterized by its 3-4 septate ascospores and its specific hepaticolous/muscicolous or terricolous habitats [FLETCHER et al., 2009]. Based on recent molecular and morphological studies, Bryophagus is included in the principally saprophytic genus Cryptodiscus [BALOCH et al., 2009]. C. gloeocapsa forms pale yellow-fawn necrotic patches on bryophytes and occurs in Europe, Macaronesia, North America, Asia and Africa [FLETCHER et al., 2009].

CYPHelium tigillare (Ach.) Ach.

Collecting site: Chornohora Mts: Mt Chornohora - meadow c. $5 \mathrm{~km} \mathrm{~W}$ of top, on wood of stump, alt. c. $1600 \mathrm{~m}, 12.10 .1994$, Z. Palice (PRA).

This lichen is recorded from several localities in Chyvchyn-Grynyavsky Mts [МАКАРЕВИч и др., 1982] and the lowland plain of Ukraine (Donetska oblast) [ОКСНЕР, 1956].

*Cystocoleus ebeneus (Dillwyn) Thwaites

Collecting site: Chornohora Mts: Mt Hoverla, on shaded sandstone rock, alt.19502000 m, 27.06.1997, Z. Palice (PRA).

This sterile cosmopolitan and monotypic genus is characterized by its dark, $10-15 \mu \mathrm{m}$ thick thallus filaments formed by nodulose to contorted hyphae with enclosed Trentepohlia photobiont [WIRTH, 1995]. Molecular data revealed its placement together with the similar lichen Racodium rupestre Pers. among mainly pathogenic Capnodiales (Dothideomycetes) [MugGia et al., 2008]. Black felty wefts belonging to Cystocoleus ebeneus or Racodium rupestre were observed by us overgrowing shaded sandstone rocks at numerous places in Chornohora Mts, but we made only one collection.

EIGLERA flavida (Hepp) Hafellner

Collecting site: Chornohora Mts: Mt Chornohora - crest c. $2 \mathrm{~km} \mathrm{~N}$ of top, on sandstone boulder, alt. c. 1900 m, 26.6.1997, Z. Palice (PRA).

The only one Ukrainian record is also from the Carpathians, Svidovets Mts [SzATALA, 1927a]. 
GYALECTA flotowii Körb.

Collecting sites: Chornohora Mts: Mt. Pietros, virgin forest at slope above Lazeshchina, Acer pseudoplatanus, alt. 1240 m, 30.6.1997, B. Buryová (PRA); Chornohora Mts: Rachiv, Luhy, virgin mixed forest along upper stream of brook Hoverla below Mt Hoverla, on bark of Acer pseudoplatanus, 8.7.2007, J. Vondrák (CBFS JV6758).

In Ukraine, the species is known from the Eastern Beskydy [KONDRATYUK et al., 2003], Svidovets [SUZA, 1927] and Chornohora regions [SUZA, 1927] in the Carpathians, and from the Yalta district in Crimea [ХОДОСОВЦЕВ, РЕДЧЕНКО, 2002; ХОДОСОВЦЕВА, 2008].

GYALECTA ulmi (Sw.) Zahlbr.

Collecting site: Chornohora Mts: Rachiv, Luhy, virgin mixed forest along upper stream of brook Hoverla below Mt Hoverla, on bark of Acer pseudoplatanus, 8.07.2007, J. Vondrák (CBFS JV6760).

In Ukrainian Carpathians, the only modern records are from Stuzhytzia and Uzhansky nature reserves [KONDRATYUK et al., 1998; KONDRATYUK, COPPINS, 2000]. It was formerly recorded from the Volcanic Carpathians [HAZSLINSZKY, 1870; SERVÍT, NÁDVORNík, 1936], Transcarpathian upland [SUZA, 1925c], Marmaroshy [HRUBY, 1925] and the Crimean Mts [ОКСНЕР, 1956; КОПАЧЕВСКАЯ, 1986].

*GYALIDEA fritzei (Stein) Vězda

Collecting site: Svidovets Mts: Rachiv, Chorna Tisza, mixed forest below saddle Okula, c. 1100 m, on sandstone, 27.6.2007, J. Vondrák (CBFS JV7065).

This European species differs from Gyalidea lecideopsis by its pale brown upper part of the hymenium and its occurrence on siliceous rocks [VĚZDA, POELT, 1991].

HelOCARPON crassipes Th. Fr.

Collecting sites: Chornohora Mts: Mt Hoverla [close to summit], on the ground and over mosses, alt. $2000 \mathrm{~m}, 15.9 .1995$, Z. Palice 5628 (PRA); ibid., over bryophytes in sandstone rock-crevices, alt. 1950-2000 m, 27.6.1997, Z. Palice 7479 (PRA); ibid., NE slope, on humus, alt. $1800 \mathrm{~m}, 15.9 .1995$, Z. Palice 7478 (PRA); ibid., over liverworts at sandstone rock underhang, alt. 1900-1950 m, 27.6. 1997, Z. Palice 7483 (PRA); Horgany Mts, Nadvirna, Stara Hutya, Mt Vysoka, alt. 1700-1800 m, on acidic soil above timber line, 2.7.2007, J. Vondrák (CBFS JV7081).

In Ukraine, this species was reported from a single site in Chyvchyn-Grynyavsky Mts [МАКАРЕВИЧ, 1947, as Lecidea crassipes]. It may be quite common above the timber line in Eastern Carpathians Mts, as indicated by four incidently collected specimens from Mt Hoverla. Some old records published as Lecidea assimilata (or as its variety) currently placed in Micarea incrassata Hedl. could belong here since this taxon used to be often misidentified for Helocarpon crassipes by old authors [see COPPINS 1983; CZARNOTA 2007].

LECANORA subintricata (Nyl.) Th. Fr.

Collecting site: Svidovets Mts: corrie N of Mt Stih, around spring of the Stanislava brook, on hard wood of Picea, alt. c. $1500 \mathrm{~m}, 30.06 .1997$, Z. Palice 12520 (PRA).

In Ukraine, there is only one unlocalized record from the Carpathians [KONDRATYUK et al., 2003]. It is a common species on wood of conifers (incl. timber), but under-collected.

\section{*LECANORA thysanophora R.C. Harris}

Collecting site: Chornohora Mts: Rachiv, Luhy, virgin mixed forest along upper stream of brook Hoverla below Mt Hoverla, on bark of Acer pseudoplatanus, 8.07.2007, J. Vondrák (CBFS JV 7062).

When sterile, this species is morphologically similar to Haematomma ochroleucum var. ochroleucum (Neck.) J.R. Laundon, but recognizable by the presence of specific terpenoids and in its fine, white and fibrous prothallus, sometimes with one or two blue-grey 
Additions to the diversity of rare or overlooked lichens and lichenicolous fungi in Ukrainian Carpathians

zones. The hyphae of the prothallus are wider $(4-5(-5,5) \mu \mathrm{m})$ than those in Haematomma ochroleucum $(3-3,5(-4) \mu \mathrm{m})$ [HARRIS et al., 2000]. It was described from eastern North America, and also found in Europe and Asia.

\section{LECIDEA erythrophaea Flörke}

Collecting site: Chornohora Mts: Rachiv, Luhy, virgin mixed forest along upper stream of brook Hoverla below Mt Hoverla, on bark of Ulmus glabra, 8.07.2007, J. Vondrák (CBFS JV7085).

In Ukraine, it was collected in Chyvchyn-Grynyavsky Mts [FAŁTYNOWICZ, Sulma, 1994] and in Uzhansky nature reserve in Eastern Beskydy [KONDRATYUK, COPPINS, 2000].

*LECIDEA pullata (Norman) Th. Fr.

Horgany Mts, Nadvirna, Bystritsa, seddle "Polonina Rushchina ", alt. c. 1450 m, on bark of Picea abies, 3.07.2007, J. Vondrák (CBFS JV7073).

This species is characterized by its sorediate thallus $(\mathrm{K}-, \mathrm{C}-, \mathrm{Pd}-)$ with discrete pale green to brown tinged soralia, c. $0,1 \mathrm{~mm}$ in diam., and presence of sphaerophorin and isosphaeric acids (UV+ white). Apothecia are rare, blackish often bluish, pruinose [APTROOT et al., 2009], absent in our material. It is very likely a common species in Eastern Carpathians, namely in montane coniferous forests. Although not explicitely listed in the species list by SUZA [1936], it was indirectly mentioned in the introductory part of the paper in stating that members of the Lecidea pullata association occur on Pinus mugo and Picea abies at high elevations of Chornohora Mts.

LECIDEA sphaerella Hedl. (Syn. Lecidea sylvana sensu Th. Fr. 1874, non Biatora sylvana Körb.)

Collecting site: Chornohora Mts: Rachiv, Luhy, virgin mixed forest along upper stream of brook Hoverla below Mt Hoverla, on bark of Ulmus glabra, 8.07.2007, J. Vondrák (CBFS JV7083).

The species is difficult to circumscribe; its biatorine, usually carneous brown to reddish-brown apothecia with receding excipulum and simple to occasionally 1-septate, narrowly ellipsoid ascospores may lead to misidentification for Biatora helvola Körb. ex Hellb., which however, contains gyrophoric acid in apothecia, has more prominent excipulum, less thickened paraphyses, and inhabits more acidic bark. The apothecia of Lecidea sphaerella soon become convex and are very variable in pigmentation, ranging from almost translucent pale to dark brown. Pale morphs of L. sphaerella may be confused with Lecania prasinoides Elenkin which, however, often has a persistent thalline margin and prefers bark or wood near water or subjected to water spray. Another similar taxon, Lecania cyrtellina (Nyl.) Sandst., differs by its very narrow ascospores [see REESE NÆSBORG 2008]. More pigmented apothecia of Lecidea sphaerella usually contain a reddish-brownish pigment in the subhymenium and upper hypothecium (visible in section).

No comprehensive description of the species exists in recent literature; for details see HEDLUND [1892]. Recent molecular analyses showed that this taxon is related to 'Catillaria' croatica and, along with the Thamnolecania group, belongs to Bilimbia s. lat. [REESE NÆSBORG et al., 2007]. The previous reports of Lecidea sphaerella from Ukraine are uncertain since the original records are based on the name Biatora sylvana Körb., which is now considered a synonym of Biatora globulosa (Flörke) Fr. [PRINTZEN, 1995].

*LeCIDELla patavina (A. Massal.) Knoph \& Leuckert

Collecting site: Chornohora Mts: ‘Hřeben mezi Čornou Horou a Menčulem`, 2.8.1934, A. Hilitzer (PRM-836966, cum Physcia caesia [det. R. Moberg] - orig. sub Parmelia encausta), det. H. Hertel. 
This species differs from L. stigmatea by its larger apothecia (up to $3 \mathrm{~mm}$ in diam.) and hymenium with oil droplets. It is distributed in Europe, Asia, North Africa, and North and South America [АНДРЕЕВ, 2003].

\section{LEPTOGIUM intermedium (Arnold) Arnold}

Collecting site: Chornohora Mts: Rachiv, Luhy, virgin mixed forest along upper stream of brook Hoverla below Mt Hoverla, on bark of Ulmus glabra, 8.7.2007, J. Vondrák (CBFS JV6784).

In Ukrainian Carpathians, this species was probably recorded by SzATALA [1923] from Chyvchyn-Grynyavsky Mts; it has been also found in Crimea [ХОДОСОвцЕВ, 2006].

\section{LEPTOGIUM teretiusculum (Wallr.) Arnold}

Collecting sites: Chornohora Mts: Rachiv, Luhy, virgin mixed forest along upper stream of brook Hoverla below Mt Hoverla, on bark of Acer pseudoplatanus, 8.7.2007, J. Vondrák (CBFS JV6756); Uholsky massive, Mala Uhol'ka, Rg Hreben', way to Chur` Mt, alt. 680 m, on bark of Quercus petraea, 26.7.2005, A. Khodosovtsev, S. Postoyalkin (KHER).

In Ukraine, this lichen has been found in Ukrainian Carpathians, Eastern Beskydy [COPPINS et al., 1998; KONDRATYUK, COPPINS, 2000; COPPINS et al., 2005] and ChyvchynGrynyavsky Mts [ZalewsKA, 1998], and in Crimea [ХОДОсовЦЕВ, РедченкО, 2002; ХОДОСОВЦЕВА, 2008].

LOPADIUM disciforme (Flot.) Kullh. (syn. Lopadium pezizoideum auct. p.p. - specim. epiph.)

Collecting site: Chornohora Mts: Rachiv, Luhy, virgin mixed forest along upper stream of brook Hoverla below Mt Hoverla, on bark of Acer pseudoplatanus, 8.7.2007, J. Vondrák (CBFS JV 7069).

In Ukraine it is recorded only in the Carpathians from Chyvchyn-Grynyavsky Mts [Sulma, 1933; FAlTYNOWICZ, Sulma, 1994] and as a common species in Chornohora Mts [SUZA, 1936]. More recently reported also from Eastern Beskydy in Stuzhytzia and Uzhansky reserves [COPPINS et al., 1998; KONDRATYUK, COPPINS, 2000].

*MelaspiLea granitophila (Th. Fr.) Coppins

Collecting site: Horgany Mts: Ust'-Chorna: the Turbat valley, below overhanging sandstone rock at narrow forest-railway, c. $7 \mathrm{~km} \mathrm{~N}$ of Mt Unharska, alt. c. $1120 \mathrm{~m}$, 14.10.1994, Z. Palice (PRA).

This species has rounded to lirellate, $0,1-0,4 \mathrm{~mm}$ long apothecia, with short ascospores $(9,5-) 11-14(-19) \times(3,5-) 4,5-5,5(-6,5) \mu \mathrm{m}$ in size [SANDERSON et al., 2009]; it is a widely distributed species in Europe but rarely collected or reported.

Micarea lithinella (Nyl.) Hedl. (Syn. Biatora meiocarpoides (Nyl.) Arnold)

Collecting site: Chornohora Mts: Rachiv: the Balzatul valley, on loose siliceous stone at road-side, alt. c. $800 \mathrm{~m}, 24.6 .1997$, Z. Palice (PRM, cum Porpidia crustulata).

This is a characteristic pioneer lichen frequently growing on semi-immersed small siliceous pebbles and stones on bare ground, and is easily overlooked. In Ukraine, it is known from Volcanic Carpathians [SERVíT, NÁDVORNík, 1932, as Biatora meiocarpoides] and Eastern Beskydy in the Carpathians [MotiejūNAITĖ et al., 1999] and Crimean Mts [ХОДОСОВцЕВ, 2004].

In the Ukrainian and eastern Carpathian checklist [KONDRATYUK et al., 1998; 2003], Biatora meiocarpoides is accepted as a good species. Nevertheless the name Lecidea (Biatora) meiocarpoides was synonymized with Lecidea lithinella Nyl. by ZAHLBRUCKNER [1890], but this was not followed, or possibly overlooked, by subsequent authors, perhaps due to the treatment of these two names separately in Catalogus Lichenum Universalis [ZAHLBRUCKNER, 1925]. Recently, based on the study of authentic material, CZARNOTA [2007] confirmed Zahlbruckner's original finding. 


\section{MICAREA marginata Coppins \& Muhr}

Collecting site: Boržava, Stoj, 1933, J. Nádvornik (BRA, as Lecidea ? pycnocarpa).

This is one of several aberrant Micarea species due to a well developed apothecial margin. It has a diverse ecology growing on splashed rocks in stream bedrocks, damp rocks in heatlands or on sheltered rocks in high elevations above the timber line in places with prolonged snow-lie [FRYDAY, 2001; CZARNOTA, 2007]. In Ukraine, it was collected by the second author in high altitudes of the Chornohora Mts; detailed localities are listed in CZARNOTA [2004]. One additional revised herbarium specimen is cited above.

*Micarea turfosa (A. Massal.) Du Rietz

Chornohora Mts: peaty spring with prolonged snow cover E of Mt Brebenyeskul, alt. c. 1900 m, 26.6.1997, Z. Palice 12938 (PRA).

This species is somewhat similar to M. botryoides, but differs, for example, in possessing larger ascospores and lacking stalked pycnidia. It is known from Europe, Asia, North and South America, and Antarctica [CZARNOTA, 2007].

Multiclavula mucida (Pers.) R.H. Petersen

Collecting sites: Chornohora Mts: the upper part of Lazeshchina valley on NNE slope of Mt Pietros, on rotten wood of stump, alt. 1100-1200 m, 9.10.1994, Z. Palice 13307 (PRA); Marmaroshy Mts: Rachiv, protected area Kuziy (limestone gorge in valley of brook influent to river Tisza), on decaying wood of Fraxinus excelsior, 9.7.2007, J. Vondrák (CBFS JV6770).

Although not mentioned in the Ukrainian checklist [KONDRATYUK et al., 1998] and the checklist of Eastern Carpathians [KONDRATYUK et al., 2003], this species appeared in mycological literature from Ukrainian Carpathians [РILÁT 1940; ЗЕРОВA та ін., 1972, as Lentaria mucida]. A recent record is mentioned by HOLEC [2008] from the valley of the river Tisza.

OCHROLECHIA microstictoides Räsänen

Collecting site: Chornohora Mts: Rachiv, Luhy, above village Hoverla below Mt Hoverla, on wood with Micarea denigrata, 8.7.2007, J. Vondrák (CBFS JV7108), det. M. Kukwa.

Recently found in Ukrainian Carpathians [KONDRATYUK et al., 2003].

*OPEgRAPHA corticola Coppins \& P. James

Collecting site: Chornohora Mts: Uholsky massive, Mala Uhol'ka, Rg Hreben', way to Chur' Mt, alt. $650 \mathrm{~m}$, at the base of Quercus petraea, 26.7.2005, A. Khodosovtsev, S. Postoyalkin (KHER).

This species is characterized by its ochre coloured punctiform soralia, 0,2-0,7 mm wide, eroded from a thin, almost invisible greyish thallus. Thallus and soralia have negative spot reactions. Apothecia and pycnidia are unknown [PENTECOST, JAMES, 2009]. It is known from Western Europe and North America.

OPEGRAPHA dolomitica (Arnold) Torrente \& Egea

Collecting site: Marmaroshy Mts, Rachiv, protected area Kuziy (limestone gorge in valley of brook influent to river Tisza), on shaded limestone rock, 9.7.2007, J. Vondrák (CBFS JV6720).

It has recently been recorded from Crimea [ХОДОСОВЦЕВ, 2004].

PachyPhiale fagicola (Hepp) Zwackh

Collecting site: Chornohora Mts: Lazeshchina valley, on bark of Acer pseudoplatanus, alt. 800-900 m, 14.9.1995, Z. Palice (PRA). 
In Ukraine, the species is known from the Carpathians and Crimean Mts [ОКСНЕР, 1956], and from the lowland plain [ZELENKO, 2006].

Peltigera venosa (L.) Hoffm.

Collecting site: Svidovets Mts: Rachiv, Chorna Tisza, Mt Dodyaska in Svidovets Mts, alt. c. $1750 \mathrm{~m}$, on calcareous soil above timber line, 28.6.2007, J. Vondrák (CBFS JV6796).

In Ukraine, all records had been made until the middle of the 20th century; records are listed in МАКАРЕВИЧ и др. [1982] and КОПАЧЕВСКАЯ [1986].

Pertusaria ophthalmiza (Nyl.) Nyl. (Syn. Pertusaria multipuncta sensu Erichsen)

Collecting site: Chornohora Mts: Mt Chornohora: meadow c. $5 \mathrm{~km} \mathrm{~W}$ of summit, on bark of solitary Acer pseudoplatanus, alt. c. 1600 m, 12.10.1994, Z. Palice (PRA).

This species diagnostic characters are soralia $(0.5-1.2 \mathrm{~mm}$ in diam.) with raised, margin covering 1-2 sunken apothecia. Negative chemical spot-reactions (aliphatic lichen acids present) and raised and irregularly crenulate margins of soralia or apothecia help to distinguish this species from similar P. multipuncta (Turner) Nyl. (non auct.). The species is known from Europe, Asia, North and Central America, and Macaronesia [CHAMBERS et al., 2009].

Although $P$. ophthalmiza is not explicitely mentioned in lichenological literature referring to Ukraine, it has been published several times from this territory under the name $P$. multipuncta; the first Ukrainian record by Hazslinszky from the surroundings of Ungvar (= Uzhgorod) was reported as P. multipuncta by ERICHSEN [1936]. Makarevich (with co-authors) [e.g. МАКАРЕВИЧ и др., 1982], and contemporary authors followed the incorrect concept of ERICHSEN [1936], which was corrected by DIBBEN [1980] and HANKO [1983]. The presence of P. multipuncta (Turner) Nyl. (non auct.) is uncertain in Ukraine and requires further investigation.

*PhaeOgraphis inusta (Ach.) Müll. Arg.

Collecting site: Marmaroshy Mts: Rachiv, protected area Kuziy (limestone gorge in valley of a tributary brook of the river Tisza), on bark of Ulmus glabra, with Opegrapha viridis and Graphis scripta, 9.7.2007, J. Vondrák (CBFS JV7079).

This is the first confirmed species of the genus in Ukraine. Another species, $P$. dendritica (Ach.) Müll. Arg., which appears in recent catalogues and lists dealing with Ukrainian Carpathians [МАКАРЕВИч и др., 1982; KONDRATYUK et al., 1998; 2003], is based on a general statement by SUZA [1925b] in his chorological review of lichens in Moravia that mentions that this species is also known from the surroundings of Uzhgorod. However, the presence of this species in Eastern Carpathians was subsequently doubted by the same author [SUZA, 1934] since the Uzhgorod record (by ? Hazslinszky) had been re-evaluated and placed under Graphis [see SzATALA, 1930]. The name P. dendritica should be deleted from upcoming Ukrainian checklist.

$P$. inusta differs from $P$. dendritica in possessing shorter, 3-5 septate ascospores. It is known from Europe, Macaronesia, Asia, North America and New Zealand [BENFIELD et al., 2009]. It has a rather strong oceanic bias in Europe and so far the most continental records were done in the sandstone area of Bohemian-Saxonian Switzerland (Northern Bohemia, the Czech Republic) [PALICE et al., 2007].

Phaeophyscia chloantha (Ach.) Moberg (Syn. Physciella chloantha (Ach.) Essl.)

Collecting site: Chornohora Mts: Uholsky massive, on bark of Malus, Velyka Uhol'ka, alt. 400 m, 8.7.2006, A. Khodosovtsev, S. Postoyalkin (KHER).

From Ukraine, Physcia pragensis $f$. tremulicola Nádv. was described by NÁDVORNÍK [1947] from surroundings of Uzhgorod. This forma, along with other infraspecific taxa described under P. pragensis Nádv., were synonymised under Phaeophyscia chloantha by 
Additions to the diversity of rare or overlooked lichens and lichenicolous fungi in Ukrainian Carpathians

MOBERG [1978]. In Uppsala herbarium database [http://www-hotel2.uu.se:8888/cgibin/wwwdrive.fytotek/beginner], two additional unpublished herbarium specimens of $P$. chloantha are present: Kyiv region (1936, leg. A. Oxner; 1989, det. R. Moberg) and L'viv region (1940, leg. [M.] Makarevich; 1989, det. R. Moberg). It has also been recorded from Eastern Beskydy [KONDRATYUK et al., 1995] and Crimea [ХОДОСОвЦЕВ, 2000].

Polyblastia cupularis A. Massal.

Collecting site: Chornohora Mts: Mt Chornohora, crest c. $2 \mathrm{~km} \mathrm{~N}$ of summit, on overhanging side of sandstone boulder, alt. c. 1900 m, 26.6.1997, Z. Palice 13320 (PRA).

It has only been recorded once from Ukrainian Carpathians, namely from Mt Smotrec in Chornohora Mts [Sulma, 1933].

*Polyblastia schaereriana (A. Massal.) Müll. Arg. (Syn. Polyblastia theleodes auct. p.p. $\max$.)

Collecting sites: Chornohora Mts: Mt Turkul, on shaded sandstone rock close to top, alt. c. $1900 \mathrm{~m}, 27.6 .1997$, Z. Palice 12754 (PRA, as Sporodictyon schaererianum); Chornohora Mts: Mt Breskul $(1911 \mathrm{~m})$, c. $1.5 \mathrm{~km}$ SE of Mt Hoverla, on semi shaded perpendicular sandstone rock, alt. c. $1900 \mathrm{~m}, 27.6 .1997$, Z. Palice 12932 (PRA, as Sporodictyon schaererianum).

This lichen is characterized by its well developed, pale areolate to verrucose thallus composed of coalescing convex areoles $(0,1-0,3 \mathrm{~mm}$ wide). Cephalodia are frequently present. Reasonably large, black, half-immersed perithecia $((0,45-) 0,7-1,2 \mathrm{~mm}$ in diam.) are frequently roughened at the apex and irregularly covered by the thallus. The ascospores are dark brown when mature, (50-)53-73(-76) $\times(29-) 31-43(-47) \mu \mathrm{m}$. It is known from Europe, Greenland and North America [ORANGE et al., 2009a].

This species was formerly often misidentified as $P$. theleodes (Sommerf.) Th. Fr. (syn. Henrica theleodes (Sommerf.) S. Savić, Tibell \& Nav.-Ros.) which has similarly sized ascospores, but the latter species tends to form a flat peltate thallus with crenulate margin, slightly lighter and narrower ascospores, and perithecia with a smooth surface; cephalodia are absent in P. theleodes [SAVIĆ, TIBELL, 2008]. Recently, based on molecular data, SAVIĆ and TIBELL [2009] placed P. schaereriana into a revived genus Sporodictyon A. Massal., where it was originally described.

Protothelenella sphinctrinoidella (Nyl.) H. Mayrhofer \& Poelt

Collecting sites: Chornohora Mts: Mt Hoverla, over decaying bryophytes on NE slope, alt. c. 1800 m, 15.9.1995, B. Gruna, Z. Palice (PRA); Ibid.: alt. 1900-1950 m, 27.6.1997, Z. Palice (PRA); Chornohora Mts: Rachiv, Luhy, virgin mixed forest along upper stream of brook Hoverla below Mt Hoverla, on soil, 8.7.2007, J. Vondrák (CBFS JV6740).

This species has rarely been collected in Ukrainian Carpathians [МАКАРЕВИЧ, 1952a, as Microglaena reducta Th. Fr.; МотІЕJŪNAITÉ et al., 1999; ХОДОСОВЦЕВ, 2008].

*Protothelenella sphinctrinoides (Nyl.) H. Mayrhofer \& Poelt

Collecting site: Chornohora Mts: on summit of Mt Hoverla, over decaying bryophytes, alt. c. $2000 \mathrm{~m}, 27.6 .1997, \mathrm{Z}$. Palice (PRA).

This lichen differs from $P$. sphinctrinoidella by its large and strongly muriform ascospores. It is known from Europe, Greenland, North America and North Asia [ORANGE et al., 2009b].

*Psilolechia clavulifera (Nyl.) Coppins

Collecting site: Svidovets Mts: valley of Stanislava brook, on bark at dry base of Picea, alt. 950 m, 30.6.1997, Z. Palice (PRA). 
The small and clavate ascospores, presence of Stichococcus and absence of pycnidia distinquish this species from morphologically similar species of Micarea. It is known from Europe, North America and Tasmania [GILBERT et al., 2009].

Psoroglaena dictyospora (A. Orange) H. Harada (Syn. Macentina dictyospora A. Orange)

Collecting site: Svidovets Mts: upper part of valley of Stanislava brook, at base of Fagus, alt. c. 1200 m, 30.6.1997, Z. Palice 12937 (PRA, as Macentina dictyospora).

This inconspicuous lichen is new to Ukrainian Carpathians; in Ukraine it is only known from Cherkas 'ka oblast [ЗЕЛЕНКО, 2001].

*Pycnora leucococca (R. Sant.) R. Sant.

Collecting sites: Horgany Mts: Mt Bratkovska, on its south slope, on hardwood bark, alt. c. 1200 m, 1.7.1997, Z. Palice (PRA); Horgany Mts: Ust'-Chorna, Turbat valley, between settlements Turbat and Ust'-Turbat, on bark of Alnus incana, alt. $750 \mathrm{~m}, 3.7 .1997$, Z. Palice (PRA).

This always sterile species differs from the chemically concordant $P$. sorophora by its subsquamulose areoles with orbicular to capitate soralia and its preference for growing on smooth bark of deciduous trees [TøNSBERG 1992; COPPINS, 2009]. It is known from Europe, Asia and North America.

Pyrenula coryli A. Massal.

Collecting site: Chornohora Mts: Uholsky massive, Mala Uhol'ka, across Buchmanskiy and Didiv streams, on bark of Corylus, 21.07.2005, A. Khodosovtsev, $S$. Postoyalkin (KHER).

It has been recorded twice from Ukrainian Carpathians, namely from the Transcarpathian upland [SUZA, 1925c, as Arthopyrenia coryli] and Svidovets Mts [SUZA, 1927].

\section{RINODINA griseosoralifera Coppins}

Collecting sites: Chornohora Mts: Uholsky massive, Mala Uhol'ka, Plechans'kiy Hrun', Zaplecha, alt. 1000 m, on bark of Fagus sylvatica, 22.7.2005, A. Khodosovtsev, S. Postoyalkin (KHER); Voyevuts ke, way to polonyna Menchul, alt. 950 m, 24.7.2005, on bark of Fagus, A. Khodosovtsev, S. Postoyalkin (KHER).

In Ukrainian Carpathians, this species was collected in Eastern Beskydy from Stuzhytzia and Uzhansky nature reserves [COPPINS et al., 1998; KONDRATYUK, COPPINS, 2000].

\section{*RINODINA orculata Poelt $\&$ M. Steiner}

Collecting site: Chornohora Mts: Lazeshchina valley, Acer pseudoplatanus close to shepherds' house, 1100-1200 m, 12.10.1994, Z. Palice (PRA), conf. H. Mayrhofer.

It was originally described as a sorediate species, but the soredia belong to another lichen [GIRALT, MAYRHOFER, 1995]. It belongs to a difficult $R$. archaea group characterized by Physconia-type ascospores tending to have narrow lumina canals in particular stages of development, and "type A" ontogeny [MAYRHOFER, SHEARD, 2007]. Three epiphytic species are accepted in Europe: $R$. archaea (Ach.) Arnold, R. orculata and R. trevisanii (Hepp) Körb., all of which may occur in Ukraine. $R$. archaea and $R$. trevisanii possess distinctly larger ascospores than $R$. orculata; for details see MAYRHOFER and SHEARD [2007]. In Ukrainian checklists [KONDRATYUK et al., 1998; 2003], only $R$. archaea is listed from this group, with $R$. trevisanii as a synonym. Additional Ukrainian specimens of $R$. orculata may be found in herbaria under these names. 
Additions to the diversity of rare or overlooked lichens and lichenicolous fungi in Ukrainian Carpathians

ROPALOSPORA lugubris (Sommerf.) Poelt

Collecting site: Chornohora Mts: Mt Turkul, on dry overhanging sandstone rock below top, alt. c. 1900 m, 27.6.1997, Z. Palice (PRA).

In Ukraine, the only one old record from Chyvchyn-Grynyavsky Mts exists [SULMA, 1933].

SARCosagium campestre (Fr.) Poetsch \& Schied.

Collecting site: Horgany Mts: Nadvirna, Bystritsa, seddle "Polonina Rushchina" in Horgany Mts, alt. c. $1450 \mathrm{~m}$, on calcareous soil on ruin wall, 3.7.2007, J. Vondrák (CBFS JV6785, 6804).

In Ukrainian lowland plain, it was collected from Chernigivs 'ka oblast [КОНДРАТюК, ЗЕЛЕНКО, 1994]. This species is new to Ukrainian Carpathians.

SCHAERERIA fuscocinerea (Nyl.) Clauzade \& Cl. Roux

Collecting site: Chornohora Mts: Mt Turkul, on exposed sandstone rock close to summit, alt. c. $1900 \mathrm{~m}, 27.6 .1997$, Z. Palice (PRA).

In Ukrainian Carpathians, it is known from Mt Pop Ivan Marmaroshskiy [SUZA, 1927, as Lecidea tenebrosa Flot.], but the record was not included in both the Ukrainian and the Eastern Carpathian checklists [KONDRATYUK et al., 1998, 2003]. Presumably, it is an undercollected lichen on acid rocks in mountainous parts of Ukraine.

SCOLICIOSPORUM sarothamni (Vain.) Vězda

Collecting site: Chornohora Mts: Uholsky massive, Mala Uhol'ka, Voyevuts 'ke, way to polonyna Menchul, alt. $1050 \mathrm{~m}$, on bark of Fagus, 24.7.2005, A. Khodosovtsev, $S$. Postoyalkin (KHER).

The species has been rarely recorded from the Ukrainian Carpathians [SERVíT, NÁDVORNÍK, 1936; COPPINS et al., 1998; KONDRATYUK, COPPINS, 2000; ХодОСОВЦЕВ, Постоялкин, 2007], but recently it has been repeatedly recorded from the lowland plain of Ukraine [ВIELCZYK et al., 2005; КОНДРАТЮК, МАРТИНЕНКО, 2006; ГАВРИЛЕНКО, ХодОСОвцЕВ, 2009].

STEINIA geophana (Nyl.) Stein

Collecting site: Horgany Mts: Nadvirna, Bystritsa, saddle "Polonina Rusccsina", alt. c. $1450 \mathrm{~m}$, on calcareous soil over ruin wall, 3.7.2007, J. Vondrák (CBFS JV6786).

In Ukrainian Carpathians, it was once recorded by SzATALA [1923].

\section{THELOCARPON epibolum Nyl.}

Collecting site: Horgany Mts, Nadvirna, Stara Huta, Mt Sivulya alt. 1700-1800 m, lichenicolous on squamules of Lichenomphalia hudsoniana in scree, 3.7.2007, J. Vondrák (CBFS JV6778, 6782).

This is an ephemeral lichen that may grow on a variety of substrates. Our sample fits microscopically to the nominal variety of the species that may grow on soil and wood, as well as on thalli of macrolichens [ORANGE et al., 2009c]. Thelocarpon epibolum var. epithallinum (Leight.) G. Salisb. which was described for lichenicolous populations on Peltigera and Solorina has distinctly bigger ascospores [SALISBURY, 1953].

In Ukraine, T. epibolum was only collected from the lowland plain [ОКСНЕР, 1956].

*THELOCARPON robustum auct. brit., non Eitner

Collecting site: Svidovets Mts: Rachiv, Chorna Tisza, in valley of river Chorna Tisza above village, on pebbles on forest road, 28.6.2007, J. Vondrák (CBFS JV6793, dupl. PRA).

Our specimen has the following characters: thalline verrucae convex, pale green-grey, c. $130-330 \mu \mathrm{m}$ in diam.; photobiont: angular isodiametric cells, small, up to $10 \mu \mathrm{m}$ in diam.; perithecia: immersed in thalline verrucae, $1(-3)$ per verruca, c. 100-150 $\mu \mathrm{m}$ in diam., with 
yellow-green pigmented excipular region; perithecial wall: hyaline, c. 10-15 $\mu \mathrm{m}$ thick; periphysoids present; hamathecium of thin, branched and anastomosed hyphae; asci $60-75 \times$ 20-30 $\mu \mathrm{m}, \mathrm{I}+$ red, with c. 100 ascospores; hymenial gel: I+ red; ascospores: c. 3-4 × 1,5-2 $\mu \mathrm{m}$.

Our specimen fits the description of Thelocarpon robustum in ORANGE et al. [2009c]. The type material of $T$. robustum Eitner was found to be conspecific with Acarospora smaragdula var. murina (Sandst.) H. Magn. [NAVARRO-RosinÉS et al., 1999].

\section{THELOPSIS rubella Nyl.}

Collecting site: Chornohora Mts: Uholsky massive, Mala Uhol'ka, Hreben', way to Chur` Mt, alt. 550 m, on bark of Acer, 26.7.2005, A. Khodosovtsev, S. Postoyalkin (KHER).

In Ukrainian Carpathians, it was once recorded from Chornohora Mts [SUZA, 1927].

ThelOTREMA suecicum (H. Magn.) P. James

Collecting sites: Chornohora Mts: Uholsky massive, Mala Uholkka, across Buchmanskiy and Didiv streams, on smooth bark of Corylus, 21.7.2005, A. Khodosovtsev, S. Postoyalkin (KHER); stream Didiv, on smooth bark of Corylus, 28.7.2005, A. Khodosovtsev, S. Postoyalkin (KHER).

In Ukraine, this rare species was recently reported from two localities based on herbarium specimens collected by J. Suza (Lichenes Bohemosl. Exs. 65) and J. Nádvorník from Svidovets Mts and Borzhava region, respectively [PURVIS et al., 1995]. SuZA [1927] considered this taxon to be a form of T. lepadinum (Ach.) Ach. and introduced for it the name T. lepadinum $f$. coryli Suza, but without a valid description (nomen nudum).

\section{TraPELIA corticola Coppins \& P. James}

Collecting sites: Chornohora Mts: Mt Pietros, old-growth forest on slope facing Lazeshchina valley, on bark of Abies, alt. c. 1300 m, 17.9.1995, Z. Palice (PRA); Svidovets Mts: uppermost part of valley of Stanislava brook, on bark of Picea, alt. c. 1300 m, 30.6.1997, Z. Palice (PRA).

In Ukrainian Carpathians, it has only been recorded in Eastern Beskydy from Stuzhytzia and Uzhansky nature reserves [COPPINS et al., 1998, 2005; KONDRATYUK, COPPINS, 2000].

*TrAPELIOPSIS glaucolepidea (Nyl.) Gotth. Schneid. (Syn. Trapeliopsis percrenata (Nyl.) Gotth. Schneid.)

Collecting site: Svidovets Mts: Rachiv, Chorna Tisza, Mt Tataruka, alt. c. $1650 \mathrm{~m}$, on acidic soil above timber line, 28.6.2007, J. Vondrák (CBFS JV7068).

This lichen is distinquished from other Trapeliopsis species by its frequently sorediate, Cladonia-like, $\mathrm{C}$ - squamules and by the presence of a UV+ glaucous unknown substance. The rounded soralia of early juvenile stages sometimes obscure the squamules and then it may remind one of some crustose sorediate species. Richly fertile specimens may be completely esorediate. It is a widely distributed species in both hemispheres, being found in Europe, East Africa, SE Asia (Papua New Guinea) and Central and South America [PALICE, Printzen, 2004; PURVIS, SMITH, 2009].

\section{TRAPELIOPSIS pseudogranulosa Coppins. \& P. James}

Collecting sites: Svidovets Mts: valley of "Svidovetsky potik" brook, on rotten wood at road-cutting, alt. 900 m, 29.6.1997, Z. Palice 13309 (PRA); Chornohora Mts: Uholsky massive, Mala Uhol'ka, polonyna Menchul, alt. $1300 \mathrm{~m}, 24.7 .2005$, A. Khodosovtsev, $S$. Postoyalkin (KHER).

In Ukrainian Carpathians, it has been recorded in Eastern Beskydy from several sites in Stuzhytzia and Uzhansky nature reserve [COPPINS et al., 1998, 2005; KONDRATYUK, COPPINS, 2000]. 
Additions to the diversity of rare or overlooked lichens and lichenicolous fungi in Ukrainian Carpathians

VAHLIELla leucophaea (Vahl) P.M. Jørg. (Syn. Fuscopannaria leucophaea (Vahl) P.M. Jørg.)

Collecting site: Marmaroshy Mts: Rachiv, protected area Kuziy (limestone gorge in valley of brook influent to river Tisza), on sun-exposed siliceous / calcareous cliff Sokoline berdo (Falcon rock), on calcareous / siliceous rock, J. Vondrák, 9.7.2007 (CBFS JV6727).

It has not been collected since the middle of the 20th century in Ukraine; records are from the Carpathians [cf. МАКАРЕВИч и др., 1982] and Crimean Mts [cf. КОПАЧЕВСКАЯ, 1986].

\section{VERRUCARIA sorbinea Breuss}

Collecting site: Chornohora Mts: Uholsky massive, Mala Uhol'ka, Rg Hreben', way to Chur` Mt, alt. 650 m, on bark of Quercus petraea, 26.7.2005, A. Khodosovtsev, S. Postoyalkin (KHER).

In Ukraine, it has only been collected in Crimea [ХоДОсовцЕВ, ХодОсовцЕВА, 2007]; a previous Carpathian record is from Slovakia [GUTTOVÁ, PALICE, 2005]. According to PYKÄLÄ [2010], V. sorbinea may be conspecific with V. kondaensis Vain.

VezdAEA aestivalis (Ohl.) Tsch.-Woess \& Poelt

Collecting sites: Svidovets Mts: valley of "Svidovetsky potik" brook, on plant debris at road-side, alt. 800-900 m, 29.6.1997, Z. Palice 13284 (PRA); Svidovets Mts: valley of Stanislava brook, over bryophytes on bark of Acer pseudoplatanus and Fagus, alt. 1100-1330 m, 30.6.1997, Z. Palice (PRA); Horgany Mts: N-NW slopes below unnamed summit $1704 \mathrm{~m}$, on mossy bark of Acer pseudoplatanus, alt. 1300-1400 m, 3.7.1997, Z. Palice (PRA).

In Ukraine, it has been reported from Stuzhytzia and Uzhansky nature reserves in Eastern Beskydy [COPPINS et al., 1998, 2005; KONDRATYUK, COPPINS, 2000].

\section{*VezdaEA stipitata Poelt \& Döbbeler}

Collecting sites: Chornohora Mts: NE slope Mt Hoverla, over decaying bryophytes (Distichium capillaceum) together with Micarea cf. botryoides, alt. c. 1800 m, 15.9.1995, B. Gruna, Z. Palice (PRA); Svidovets Mts: valley of Stanislava brook, over bryophytes on bark of Acer pseudoplatanus, alt. c. 1150 m, 30.6.1997, Z. Palice (PRA, cum Vezdaea aestivalis).

Both specimens were found randomly in samples of other lichens and contain only a few apothecia. However, they were easily identified by their stalked apothecia and absence of "leprarioid" thallus characteristic of the similar V. leprosa (P. James) Vězda. It is known from Europe, Macaronesia, Asia and North America [TschermaK-WoESS, PoELT, 1976].

\section{Lichenicolous and lichen-allied fungi}

*ARTHRORHAPHIS aeruginosa R. Sant. \& Tønsberg

Collecting site: Horgany Mts, Nadvirna, Stara Hutya, alt. 1700-1800 m, on acidic soil above timber line, lichenicolous on Cladonia sp., 3.7.2007, J. Vondrák (CBFS JV6745).

This lichenicolous species forms characteristic blue necroses on Cladonia squamules; it is known from Europe and North America [DUKE, PURVIS, 2009].

\section{*EPIGLOEA medioincrassata (Grumm.) Döbbeler}

Collecting site: Svidovets Mts: valley of "Svidovetsky potik" brook, on wood, alt. 800-900 m, 29.6.1997, Z. Palice 13329 (PRA).

This non-lichenized fungus often grows on algal films over wood, bryophytes etc., together with ephemeral lichens such as Absconditella and Thelocarpon. It is characterized by its 3-septate ascospores, (18-)24-33(-38) $\times 3,5-5(-5,5) \mu \mathrm{m}$, with apical appendages, and 8spored asci [DÖBBELER, 1984]. It is known from Europe and North America [FRYDAY, 2004]. 
MiLOSPIUM graphideorum (Nyl.) D. Hawksw.

Collecting site: Nevické Podhradí (Nevyc'ke, c. $10 \mathrm{~km}$ NE of Uzhgorod), on andesite rock, lichenicolous on Dirina aff. stenhammari (Arnold) Poelt \& Follmann, 1929, J. Nádvornik (PRM, in sample of Arthonia lobata).

In Ukraine, the species was recently recorded in Crimea [KHODOSOVTSEV et al., 2007].

*Monodictys epilepraria Kukwa \& Diederich

Collecting site: Chornohora Mts: Uholsky massive, Mala Uhol'ka, alt. $745 \mathrm{~m}$, on Lepraria jackii, 20.7.2005, A. Khodosovtsev, S. Postoyalkin (KHER).

This recently described hyphomycete, which is lichenicolous on Lepraria, is characterized by its black multicellular (15-60 cells), globose to shortly ellipsoid conidia, 6$25(-30) \times 5-20 \mu \mathrm{m}$ in size. It was described from Europe on the basis of material from the Czech Republic, Great Britain, Lithuania, Poland, Spain and Sweden [KUKWA, DiEDERICH, 2005]. Subsequently it was reported from other European countries and also from the Canary Isles [e.g. CZYŻEWSKA et al., 2008; ERTZ, DIEDERICH, 2009].

\section{*SCLEROCOCCUM griseisporodochium Etayo}

Collecting site: Marmaroshy Mts: Rachiv, protected area Kuziy (limestone gorge in valley of brook influent to river Tisza), on shaded limestone rock, lichenicolous on Opegrapha sp., 9.7.2007, J. Vondrák (CBFS JV6781).

This species was described as a lichenicolous fungus, but according to SMITH [2009], it has its own lichenized thallus. It is known from Europe [e.g. VONDRÁK et al., 2007b].

\section{Tremella lichenicola Diederich}

Collecting site: Svidovets Mts: Rachiv, Chorna Tisza, in valley of river Chorna Tisza above village, on Larix, lichenicolous on Mycoblastus fucatus, 28.6.2007, J. Vondrák (CBFS JV6807).

Only recorded in Eastern Beskydy, from Stuzhytzia and Uzhansky nature reserves [COPPINS et al., 1998; KONDRATYUK, COPPINS, 2000].

\section{Acknowledgements}

We are grateful to Hannes Hertel, Martin Kukwa, Helmut Mayrhofer, Christian Printzen, Roland Moberg and Leif Tibell for their appraisal of several critical specimens, and to Mark Seaward who kindly made linguistic corrections and helpful criticisms. Curators of herbaria BRA and PRM are thanked for loan of the lichen material for revision. ZP acknowledges continuing support by the Academy of the Czech Republic (AV0Z60050516) and by the Ministry of Education, Youth and Sports of the Czech Republic (0021620828).

\section{Literature}

АндРЕЕВ М.П. Сем. Lecanoraceae. / В кн. Андреев М.П., Бредкина Л.И., Голубкова Н.С. и др. Определитель лишайников России. Вып. 8. Бацидиевые, Катиляриевые, Леканоровые, Мегалариевые, Микобилимбиевые, Ризокарповые, Трапелиевые. - Спб.: Наука, 2003. - С. 111-184.

АндРєнко Т., АРтЕменко В., БІляк М. та ін. Заповідники і національні природні парки України. - К.: Вища школа, 1999. - 232 с.

ГАВРИЛЕНКО Л.М., ХОДОсовцЕВ А.Е. Лишайники та ліхенофільні гриби Бургунської балки (Херсонська область) // Чорноморськ. бот. ж. - 2009. - Т. 5, № 1. - С. 28-36.

ЗЕЛЕнко С.Д. Новий для ліхенофлори України рід Macentina Vězda (Ascomycota, Verrucariaceae) // Укр. ботан. журн. - 2001. - Т. 58, № 1. - С. 86-89.

ЗЕЛЕНКО С.Д., КОНДРАТЮК С.Я. Нові види лишайників для ліхенофлори України // Укр. ботан. журн. 1994. - Т. 51, № 6. - С. 92-98.

ЗЕЛЕнко С.Д. Ліхенізовані гриби / У кн.: Кагало О.О., Шевера М.В., Леванець А.А. (ред.). Біорізноманіття Кам'янець-Подільського. Попередній критичний інвентаризаційний чекліст рослин, грибів та тварин. - Львів: Ліга-Пресс, 2004. - С. 46-57.

ЗЕРОВА М.Я., РАДЗІєВСьКИЙ Г.Г., ШЕВчЕНКО С.В. Визначник грибів України. Базидіоміцети. Екзобазидіальні, Афілофоральні, Кантареляльні. - Т. 1, книга 1. - К.: Наук. думка, 1972. - 240 с. 
Additions to the diversity of rare or overlooked lichens and lichenicolous fungi in Ukrainian Carpathians

МАКАРЕВИч М.Ф. Лишайники, зібрані в Радянських Західних Карпатах в 1940 році // Ботан. журн. АН УРСР. - 1947. - Т. 4, №1/2. - С. 111-127.

МАКАРЕВИЧ М.Ф. Цікаві види лишайників, що зібрані в Закарпатському регіоні // Ботан. журн. АН УРСР. $-1950 .-$ Т. 7, № 1. - С. 82-92.

МАКАРЕВИЧ М.Ф. Нові і цікаві лишайники з ліхенофлори УРСР // Ботан журн. АН УРСР. - 1952а. - Т. 9, № 2. - C. 44-55.

МАКАРЕВИЧ М.Ф. Цікаві піреноліхени із Закарпатської області // Ботан. журн. АН УРСР. - 1952б. - Т. 9, № 4. - С. 87-89.

МАКАРЕВИЧ М.Ф. Новий вид роду Acrocordia // Ботан. журн. АН УРСР. - 1954а. - Т. 11, № 2. - С. $75-77$.

МАКАРЕВИЧ М.Ф. Два нових види роду Lecanora // Ботан. журн. АН УРСР. - 1954б. - Т. 11, № 4. - С. 59-65.

МАКАРЕВИЧ М.Ф. До флори лишайників Чернівецької області // Ботан. журн. АН УРСР. - 1955. - Т. 12 , № 5. - С. 52-59.

МАКАРЕВИЧ М.Ф. Аналіз ліхенофлори Українських Карпат. - К.: Вид-во АН УССР, 1963. - 265 с.

МАКАРЕВИЧ М.Ф., НАВРОЦКАЯ И.Л., ЮДИНА И.В. АтЛас географического распространения лишайников в Украинских Карпатах. - К.: Наук. думка, 1982. - 403 с.

КОНдРАТЮК С.Я., БЛЮМ О.Б. Нові та рідкісні для ліхенофлори УРСР види лишайників // Укр. ботан. журн. - 1985. - Т. 42, № 4. - С. 67-70.

КОНДРАТЮК С.Я., МАРТИНЕНКО В.Г. Ліхеноіндикація. - Київ-Кіровоград: ТОВ «КОД», 2006. - 260 с.

КОПАЧЕВСКАЯ Е.Г. Лихенофлора Крыма и ее анализ. - К.: Наукова думка, 1986. - 296 с.

Котлов Ю.В. Предварительный чеклист лишайников семества Catillariaceae // Нов. сист. низш. раст. 2004. - T. 37. - C. 234-252.

ОкСНЕР А.М. Флора лишайників України. - К.: Вид-во АН УРСР, 1956. - Т. 1. - 495 с.

ОкснЕР А.М. Флора лишайників України. - Київ: Вид-во АН УРСР. Інст. Ботаніки, 1968. - Т. 2, вип. 1. $500 \mathrm{c}$.

ОкснеР А.М., КОНДРАТюК С.Я. Рід 150. Калоплака - Caloplaca Th. Fr. - В кн.: Окснер А.М. Флора лишайників України. - К.: Наук. думка, 1993a. - Т. 2, вип. 2. - С. 390-490.

ПостоялкІн C.B. Сучасний стан популяції Lobaria pulmonaria (L.) Hoffm. в Угольському масиві Карпатського біосферного заповідника // Наукові основи збереження біотичної різноманітності. - Львів: Ліга-Прес, 2006. - Вип. 7. - С. 9-11.

ПостоялКІн С.В., ХодОСОВцЕВ О.С., СуХАРЮк Д.Д. Лишайники Українсько-Швейцарської модельної ділянки Угольского масиву Карпатського біосферного заповідника // Чорноморськ. бот. ж. 2007. - Т. 3, № 2. - С. 5-11.

СМЕРЕЧИНСьКА Т.А Лишайники природного заповідника "Медобори". - Дис. ... канд. біол. наук: 03.00.21 - мікологія. - Київ, 2006. - 277 с.

Титов А.Н. Caliciales Горного Крыма // Нов. сист. низш. раст. - 1998. - Т. 32. - С. 87-92.

УРБАНАВиЧЮс Г.П. Род Brodoa Goward в России // Нов. сист. низш. раст. - 2001. - Т. 34[2000]. - С. $195-$ 206.

ХодосовцЕВ О.С. Лишайники причорноморських степів України. - Київ: Фітосоціоцентр, 1999. - 236 с.

ХодосовцЕВ О.С. Нові для Криму та України види лишайників // Укр. ботан. журн. - 2000. - Т. 57 , № 5. - С. 612-615.

ХодосовЦЕВ О.Є. Анотований список лишайників Карадазького природного заповідника // Вісті Біосферного заповідника "Асканія-Нова". - 2003. - Т. 5. - С. 31-43.

ХодосовцЕВ О.С. Лишайники кам`янистих відслонень Кримского півострова: Дис... д-ра биол. наук: 03.00.21. - Київ, 2004. - 812 с.

Ходосовцев О.Є. Нові для Кримського півострова види лишайників // Чорноморськ. бот. ж. - 2006. - Т. 2, № 1. - C. 98-103.

Ходосовцев А.Е. Род Candellariella (Candelariaceae, Lecanorales) юга Украины // Нов. сист. низш. раст. 2005. - T. 39. - C. 233-248.

Ходосовцев О.С. Нові та рідкісні для України види лишайників з півдня степової зони // Укр. ботан. журн. - 2008. - Т. 65, № 2. - С. 234-241.

ХодосовЦЕВ О.Є., БОГДАН О.В. Анотований список лишайників Ялтинського гірсько-лісового природного заповідника // Чорноморськ. бот. ж. - 2005. - Т.1, № 1. - С. 117-132.

ХодоСовцЕВ О.С., БогдАН О.В. Анотований список лишайників Кримського природного заповідника // Чорноморськ. бот. ж. - 2006. - Т.2, № 1. - С. 95-117.

ХодосовцЕВ О.С., РЕДЧЕНКО О.О. Анотований список лишайників заповідника “Мис Март’ян” // Укр. ботан. журн. - 2002. - Т. 59. № 1. - С. 64-71.

Ходосовцев О.Є., ХодосовцЕВА Ю.А. Нові для України види епіфітних лишайників з урбанізованих екосистем Ялтинського амфітеатру // Укр. ботан. журн. - 2007. - Т. 64, № 2. - С. 258-265.

Aptroot A., Gilbert O.L., Hawksworth D.L., Coppins B.J. Lecidea Ach. (1803) / In: The Lichens of Great Britain and Ireland (Smith C.W. et al., eds). - London, 2009. - P. 502-519.

Arup U., Arneng E., Søchting U. Caloplaca fuscorufa a misunderstood species in northern Europe // Lichenologist. - 2007. - Vol. 39, N 5. - P. 409-414. 
Baloch E., Gilenstam G., Wedin M. Phylogeny and classification of Cryptodiscus, with a taxonomic synopsis of the Swedish species // Fungal Diversity. - 2009. - Vol. 38. - P. 51-68.

Benfield B., Coppins B.J., James P.W. Phaeographis Müll. Arg. (1882) / In: The Lichens of Great Britain and Ireland (Smith C.W. et al., eds). - London, 2009. - P. 691-693.

Bielczyk U., Bylińska E., CZARnota P., CZyżEwska K., GuZow-Krzemińska B., Hachulka M., KiszKa J., Kowalewska A., KrZewicka B., KuKwa M., LeŚniAŃsKi G., Śliwa L., ZalewsKa A. Contribution to the knowledge of lichens and lichecolous fungi of western Ukraine // Polish Bot. J. - 2005. - Vol. 50, N 1. - P. 39-64.

BREuSs O. Eine neue Verrucaria-Art mit Goniocystenthallus // Linzer Biol. Beitr. - 1998a. - B. 30, N 1. - S. $277-279$.

BREUSS O. Drei neue holz- und borkenbewohnende Verrucaria-Arten mit einem Schlüssel der bisher bekannten Taxa // Linzer Biol. Beitr. - 1998b. - B. 30, N 2. - S. 831-836.

Chambers S.P., Gilbert O.L., James P.W., Aptroot A., Purvis O.W. Pertusaria DC. (1805). - In: The Lichens of Great Britain and Ireland (Smith C.W. et al., eds). - London, 2009. - P. 673-687.

Coppins B.J. A taxonomic study of the lichen genus Micarea in Europe // Bull. Br. Mus. nat. Hist. (Bot.). 1983. - Vol. 11, N 2. - P. 17-214.

CoppINs B.J. Pycnora Hafellner (2001) / In: The Lichens of Great Britain and Ireland (Smith C.W. et al., eds). London, 2009. - P. 771-772.

Coppins B.J., Apтroot A. Bacidia De Not. (1846) / In: The Lichens of Great Britain and Ireland (Smith C.W. et al., eds). - London, 2009. - P. 189-207.

Coppins B.J., JAMES P.W. New or interesting British lichens V // Lichenologist. - 1984. - Vol. 16. - P. 241-264.

Coppins B., Kondratyuk S., Khodosovtsev A., Wolseley P., Zelenko S. New for Crimea and Ukraine species of the lichens // Ukr. Botan. Zhurn. - 2001. - Vol. 58, N 6. - P. 716-722.

Coppins B.J., Kondratyuk S.Y., Khodosovtsev A.Y., Zelenko S.D., Coppins A.M., Wolseley P.A., VIRCHENKO V.M. Diversity of lichens and mosses of Regional Landscape Park 'Stuzhytzia' (Ukrainian Part of the International Biosphere Reserve 'Eastern Carpathians') // Lobarion lichens as indicators of the primeval forests of the Eastern Carpathians. - Darwin International Workshop, 25-30 May, 1998, Kostrino, Ukraine. - K.: Phytosociocentre, 1998. - P. 139-161.

Coppins B.J., Kondratyuk S.Y., Khodosovtsev A.Y., Zelenko S.D., Wolseley P.A. Contribution to lichen flora of Ukrainian Carpathians // Chornomors`k. botan. z. - 2005. - Vol. 1, N 2. - P. 5-23.

Czarnota P. New and some rare species of the genus Micarea (Micareaceae) in the lichen flora of Poland // Polish Bot. J. - 2004. - Vol. 49, N 2. - P. 135-143.

Czarnota P. The lichen genus Micarea (Lecanorales, Ascomycota) in Poland // Polish Bot. Studies. - 2007. Vol. 23. - P. 1-199.

Czarnota P., Coppins B.J. A new species of Agonimia and some interesting lichens from Gorce Mts (Western Beskydy Mts) new to Poland // Graphis Scripta. - 2000. - Vol. 11, N 2. - P. 56-60.

Czarnota P., Kukwa M. Contribution to the knowledge of some poorly known lichens in Poland. 1. The genus Absconditella // Folia Cryptog. Estonica. - 2008. - Fasc. 44. - P. 1-7.

Czyżewska K., HachuŁKa M., ŁUBeK A., ZANIEwski P. Distribution of some lichenicolous fungi in Poland. II. // Acta Mycol. - 2008. - Vol. 43, N 2. - 193-206.

DibBen M.J. The Chemosystematics of the Lichen Genus Pertusaria in North America North of Mexico // Publications in Biology and Geology. Milwaukee: Milwaukee Public Museum Press. - 1980. - N 5. - P. $1-162$.

Diederich P., PAlice Z., ERTZ D. Cheiromycina ananas is a synonym of Dictyocatenulata alba, a widespread, lichenized, synnematous hyphomycete herewith reported as new for Europe // Sauteria. - 2008. - B. 15. - S. 205-214.

Dietrich M., BÜRGI-MeYER K. Die Toregg in der UNESCO Biosphäre Entlebuch (LU), ein wertvoller Lebensraum für Flechten. Calicium pinastri und Micarea turfosa neu für die Schweiz // Meylania. 2008. - N 41. - S. 28-34.

DöBBELER P. Symbiosen zwischen Gallertalgen und Gallertpilzen der Gattung Epigloea (Ascomycetes) // Beih. Nova Hedwigia. - 1984. - B. 79. - S. 203-239.

Duke T., Purvis O.W. Arthrorhaphis Th. Fr. (1860) / In: The Lichens of Great Britain and Ireland (Smith C.W. et al., eds). - London, 2009. - P. 189-207.

ERTz D., Diederich P. Lichens and lichenicolous fungi new for Tenerife (Canary Islands). // Cryptogamie, Mycologie - 2009. - Vol. 29, N 4 [2008]. - P. 389-396.

FaŁtynowicz W., Sulma T. Materials to the flora of lichenized Ascomycotina of the Czywczyn Mts. (Eastern Carpathians, Ukraine). Part II // Herzogia. - 1994. - B. 10. - S. 93-98.

Fletcher A., Laundon J.R. Caloplaca Th. Fr. (1860) / In: The Lichens of Great Britain and Ireland (Smith C.W. et al., eds). - London, 2009. - P. 245-273.

Fletcher A., Purvis O.W., James P.W. Bryophagus Nitschke ex Arnold (1862). - In: The Lichens of Great Britain and Ireland (Smith C.W. et al., eds). - London, 2009. - P. 179-181.

FrYDAY A.M. Bryonora rhypariza (Nyl.) Poelt - new to North America // Evansia. - 2000. - Vol. 17, N 1. - P. $37-39$. 
FRYDAY A.M. The lichen vegetation associated with areas of late snow-lie in the Scottish Highlands // Lichenologist. - 2001. - Vol. 33, N 2. - P. 121-150.

FRYDAY A.M. A new species of Fuscopannaria with a green photobiont, and other taxonomic innovations and new records of lichenized-fungi from Alaska // Bryologist. - 2004. - Vol. 107, N 2. - P. 173-179.

Gilbert O.L., Coppins B.J., Purvis O.W. Psilolechia A. Massal. (1860) / In: The Lichens of Great Britain and Ireland (Smith C.W. et al., eds). - London, 2009. - P. 762-763.

Groner U. Neue, seltene und interessante Flechten $1 / /$ Meylania. - 2005. - N 34. - S. 8-10.

Guttová A., PALICE Z. Lišajníky Národného parku Muránska planina III - Cigánka. Lichens of the Muránska Planina National Park III - Cigánka // Reussia. - 2005. - Vol. 1, Suppl. 1 [2004]. - P. 11-47.

Hafellner J., Petutschnig W., TAurer-Zeiner C., Mayrhofer H. Über einige bemerkenswerte Flechtenfunde in Kärnten, hauptsächlich in den Gurktaler Alpen // Carinthia II. - 2005. - B. 195/115. S. 423-440.

HAFELlnER J., TÜRK R. Die lichenisierten Pilze Österreichs - eine Checkliste der bisher nachgewiesenen Arten mit Verbreitungsangaben // Stapfia. - 2001. - B. 76. - S. 3-167.

Hanko B. Die Chemotypen der Flechtengattung Pertusaria in Europa // Bibl. Lichenol. - 1983. - B. 19. - S. 1-297.

HARris R.C., Brodo I.M., TøNSBERG T. Lecanora thysanophora, a common leprose lichen in eastern North America // Bryologist. - 2000. - Vol. 103, N 4. - P. 790-793.

HARRIS R.C., LENDEMER J.C. A review of Lecania croatica (syn. Catillaria croatica) in North America// Opuscula Philolichenum. - 2010. - Vol. 8. - P. 41-49.

HAZSLINSZKY F. Adatok Magyarhon zuzmóvirányához // Math. és Term. Közlem., 1869. - 1870. - N 7. - P. 43-73.

Hermansson J., Pystina T. Calicioid lichens and fungi in the Komi Republic, Russia // Symb. Bot. Upsal. 2004. - Vol. 34, N 1. - P. 97-105.

Hertel H., Rambold G. On the genus Adelolecia (lichenized Ascomycotina, Lecanorales) // Bibl. Lichenol. 1995. -Vol. 57. - P. 211-230.

HILITZER A. Ad distributionem lichenum in Carpatis orientalibus // Preslia, 1939-1940. - 1940. - N 18-19. - S. 77-87.

HOLEC J. Interesting macrofungi from the Eastern Carpathians, Ukraine and their value as bioindicators of primeval and near-natural forests // Mycologia Balcanica. - 2008. - N 5. - P. 55-67.

HRUBY J. Die Vegetationsverhältnisse Karpatho-Russlands und der östlichen Slovakei // Bot. Arch. - 1925. - B. 11. - S. 203-271.

JONSSON F. Calicium pinastri new to Sweden // Graphis Scripta. - 2003. - Vol. 14, N 1. - P. 5-6.

JÜRIADO I., LÕHMUS P., SAAG L. Supplement to the second checklist of lichenized, lichenicolous and allied fungi of Estonia // Folia Cryptog. Estonica. - 2000. - Fasc. 37. - P. 21-27.

KeISSLER K. VON. Pyrenulaceae bis Mycoporaceae, Coniocarpineae. - In: Dr. L. Rabenhorst's KryptogamenFlora von Deutschland, Oesterreich und der Schweiz, Bd. IX, Abt. 1, Teil 2. - Leipzig: Borntraeger, 1938. - S. 1-846.

Khodosovtsev A., VondrÁK J., ŠOun J. New lichenized and lichenicolous fungi for the Crimean peninsula (Ukraine) // Chornomors'k. bot. z. - 2007. - Vol. 3, N2. - P. 109-118.

Kondratyuk S.YA., CopPINS B.J. Basement for the lichen monitoring in Uzhansky National Nature Park, Ukrainian part of the Biosphere Reserve 'Eastern Carpathians' // Roczniki Bieszczadzkie. - 2000. - N 8 [1999]. - P. 149-192.

Kondratyuk S.Ya., Khodosovtsev A.Ye., Zelenko S.D. The second checklist of lichen forming, lichenicolous and allied fungi of Ukraine. - Kiev: Phytosociocentre, 1998. - $180 \mathrm{p}$.

Kondratyuk S.YA., PopOVA L.P., LACKOviČOvÁ A., PIŠÚT I. A catalogue of the Eastern Carpathian Lichens. Kiev-Bratislava: M.H. Kholodny Institute of Botany, 2003. - 264 p.

KROG H. Taxonomic studies in Hypogymnia intestiniformis complex // Lichenologist. - 1974. - Vol. 6. - P. 135140.

KuKwa M., Diederich P. Monodictys epilepraria, a new species of lichenicolous hyphomycetes on Lepraria // Lichenologist. - 2005. - Vol. 37, N 3. - P. 217-220.

Kukwa M., Schiefelbein U., Czarnota P., Halda J., Kubiak D., Palice Z., Naczk A. Notes on some noteworthy lichens and allied fungi found in the Białowieża primeval forest in Poland // Bryonora. 2008. - Vol. 41. - P. 1-11.

Lieth H., BerlekAmp J., Fuest S., Riediger S. Climate diagram world atlas. - Leiden: Backhuys Publishers, 1999.

LiSICKÁ E. The Lichens of the Tatry Mountains. - Veda: Slovak Academy of Sciences, Bratislava, 2005. - 439 p.

LumbSch H.T., SchmitT I., DöRING H., Wedin M. ITS sequence data suggest variability of ascus types and support ontogenetic characters as phylogenetic discriminators in the Agyriales (Ascomycota) // Mycol. Res. - 2001. - Vol. 105, N 3. - P. 265-274.

Lynge B. Physciaceae. - In: Dr. L. Rabenhorst's Kryptogamen-Flora von Deutschland, Oesterreich und der Schweiz, Bd. IX, Abt. 6, Teil1. - Leipzig: Borntraeger, 1935. - S. 37-188.

Mayrhofer H., Sheard J.W. Rinodina archaea (Physciaceae, lichenized Ascomycetes) and related species // Bibl. Lichenol. - 2007. - Vol. 96. - P. 229-246. 
MERESCHKOWSKY C. Enumeratio lichenum in peninsula Taurica hucusque cognitorum // Bull. Soc. bot. France. - 1920. - N 67. - P. 186-197; 284-295.

Moberg R. Overlooked names and new combinations in Phaeophyscia (Lichenes) // Botaniska Notiser. - 1978. - Vol. 131. - P. 259-262.

Moruzi C., Petria E., Mantu E. Catalogul lichenilor din România // Acta Bot. Horti Bucurest. - 1967. - P. 1-389.

MotiejunAité J., CZYŻEWSKA K. Additions to the biota of lichens and lichenicolous fungi of Poland, with a note on Lecania prasinoides in eastern and central Europe // Polish Bot. J. - 2008. - Vol. 53, N 2. - P. 155-162.

Motiejūnaité J., Zalewska A., Kukwa M., FaŁtynowicz W. New for Ukraine or interesting lichens and allied fungi from the Regional Landscape Park `Stuzhytzia`// Ukr. Botan. Zhurn. - 1999. - Vol. 56, N 6. - P. 596-597.

MraK T., MAYRhOfer H., BAtiČ F. Contributions to the lichen flora of Slovenia XI. Lichens from the vicinity of Lake Bohinj (Julian Alps) // Herzogia. - 2004. - B. 17. - S. 107-127.

Muggia L., Hafellner J., Wirtz N., Hawksworth D.L., Grube M. The sterile microfilamentous lichenized fungi Cystocoleus ebeneus and Racodium rupestre are relatives of plant pathogens and clinically important dothidealean fungi // Mycol. Res. - 2008. - Vol. 112. - P. 50-56.

NÁDVorníK J. Lišejníky Podkarpatské Rusi // Sborn. Př́rod. K1., Brno. - 1932. - R. 15. - S. 90-99.

NÁDVORNík J. Systematische Übersicht der mitteleuropäischen Arten der Flechtenfamilie Caliciaceae // Stud. Bot. Čech. - 1942. - Vol. 5, N 1-2. - P. 6-40.

NÁDVORNík J. Physciaceae Tchécoslovaques // Stud. Bot. Čechosl. - 1947. - Vol. 8, N 2-4. - P. 69-124.

NAvarro-Rosinés P., RouX C., Bellemère A. Thelocarpella gordensis gen. et sp. nov. (Ascomycetes lichenisati, Acarosporaceae) // Can. J. Bot. - 1999. - Vol. 77, N 6. - P. 835-842.

Orange A., Purvis O.W. Agonimia Zahlbr. (1909) / In: The Lichens of Great Britain and Ireland (Smith C.W. et al., eds). - London, 2009 - P. 136-138.

Orange A., Purvis O.W., James P.W. Polyblastia A. Massal. (1852) / In: The Lichens of Great Britain and Ireland (Smith C.W. et al., eds). - London, 2009a. - P. 722-727.

Orange A., Purvis O.W., James P.W. Protothelenella Räsänen (1943) / In: The Lichens of Great Britain and Ireland (Smith C.W. et al., eds). - London, 2009b. - P. 755-757.

Orange A., Watson M.F., James P.W., Moore D.M. Thelocarpon Nyl. (1853) / In: The lichens of Great Britain and Ireland (Smith C.W. et al., eds). - London, 2009c. - P. 884-888.

Palice Z., Guttová A., Halda J.P. Lichens new for Slovakia collected in the National Park Muránska planina (W Carpathians). - In: Lackovičová A., Guttová A., Lisická E., Lizoň P. (eds), Central European lichens - diversity and threat. - Ithaca: Mycotaxon Ltd., 2006. - P. 179-192.

PAlice Z., Printzen C. Genetic variability in tropical and temperate populations of Trapeliopsis glaucolepidea: evidence against long-range dispersal in a lichen with disjunct distribution // Mycotaxon. - 2004. - Vol. 90, N 1. - P. 43-54.

Palice Z., Slavíková-Bayerová Š., Peksa O., Svoboda D., KuČerová L. The lichen flora of the Bohemian Switzerland National Park (Czech Republic) / In: Härtel H., Cílek V., Herben T., Jackson A., Williams R.B. (eds), Sandstone Landscapes. - Praha: Academia, 2007. - P. 200-204.

Pentecost A., James P.W. Opegrapha Ach. (1809) / In: The Lichens of Great Britain and Ireland (Smith C.W. et al., eds). - London, 2009. - P. 631-647.

PILÁT A. Hymenomycetes Carpatorum orientalium // Sborník Národního Musea v Praze. - 1940. - 2B (3). - S. 37-80.

Poelt J. Bryonora, eine neue Gattung der Lecanoraceae // Nova Hedwigia. - 1983. - B. 38. - S. 73-111.

Poelt J., Obermayer W. Beiträge zur Kenntnis der Flechtenflora des Himalaya II. Die Gattung Bryonora (Lichenes, Lecanoraceae) zugleich eine Revision aller Arten // Nova Hedwigia. - 1991. - B. 53., N 1-2. - S. 1-26.

Printzen C. Die Flechtengattung Biatora in Europa // Bibl. Lichenol. - 1995. - B. 60. - S. 1-275.

Printzen C., LumbSCH H.T., Schmitt I., FeIGe G.B. A study on the genetic variability of Biatora helvola using RAPD markers // Lichenologist. - 1999. - Vol. 31, N 5. - P. 491-499.

PRintzen C., PAlice Z. The distribution, ecology and conservational status of the lichen genus Biatora in Central Europe // Lichenologist. - 1999. - Vol. 31, N 4. - P. 319-335.

Printzen C., Tønsberg T. The lichen genus Biatora in northwestern North America // Bryologist. - 2000. Vol. 102, N 4 [1999]. - P. 692-713.

Purvis O.W., Jørgensen P.M., James P.W. The lichen genus Thelotrema Ach. in Europe // Bibl. Lichenol. 1995. - Vol. 58. - P. 335-360.

Purvis O.W., Smith C.W. Trapeliopsis Hertel \& Gotth. Schneid. (1980) / In: The Lichens of Great Britain and Ireland (Smith C.W. et al., eds). - London, 2009. - P. 908-910.

PYKÄLÄ J. Additions to the lichen flora of Finland. IV // Graphis Scripta. - 2010. - Vol. 22, N 1. - P. 18-27.

REDINGER K. Familie Arthoniaceae. - In: Dr. L. Rabenhorst's Kryptogamen-Flora von Deutschland, Oesterreich und der Schweiz. - Bd. IX, Abt. 2, Teil 1. - Leipzig: Borntraeger, 1937. - S. 1-180.

REESE NÆSBORG R. Taxonomic revision of the Lecania cyrtella group based on molecular and morphological evidence // Mycologia. - 2008. - Vol. 100, N 3. - P. 397-416. 
REESE NÆSBORg R., EKMAN S., TiBell L. Molecular phylogeny of the genus Lecania (Ramalinaceae, lichenized Ascomycota) // Mycol. Res. - 2007. - Vol. 111. - P. 581-591.

SAlisBuRY G. The genus Thelocarpon in Britain // North West Naturalist - 1953 - Vol. 1953. - P. 66-76.

SAnderson N.A., HAwksworth D.L., Aptroot A. Melaspilea Nyl. (1857). - In: The lichens of Great Britain and Ireland (Smith C.W. et al., eds). - London, 2009. - P. 576-579.

SAVić S., TiBell L. The lichen genus Henrica (Verrucariaceae, Eurotiomycetes) in northern Europe // Nord. J. Bot. - 2008. - Vol. 26. - P. 237-247.

SAVić S., Tibell L. Taxonomy and species delimitation in Sporodictyon (Verrucariaceae) in Northern Europe and the adjacent Arctic - reconciling molecular and morphological data // Taxon - 2009. - Vol. 58, N 2. - P. 585-605.

SÉRusiauX E., Diederich P., BrAND A.M., BoOM P. van den. New or interesting lichens and lichenicolous fungi from Belgium and Luxembourg. VIII // Lejeunia. - 1999. - Vol. 162. - P. 1-96.

SERvít M. Dvě československé lokality lišejníku Belonia russula Krb. // Čas. Nár. Mus., sect. Natur. - 1925. R. 99. - S. 139-141.

Servít M., ČERnOHORSKÝ Z. Flechten aus Čechoslovakei. IV. Malá Fatra, Velká Fatra und Choč-Gruppe in Slovakei nebst Nachträgen // Věstn. Král. Čes. Spol. Nauk., Tř. Mat.-Př́rí, 1934. - 1935. - S. 1-34.

SERvít M., NÁdvorNíK J. Flechten aus der Čechoslovakei. II. Karpatorussland und Südostslovakei // Věstn. Král. Čes. Spol. Nauk., Tř. Mat.-Přír., 1931. - 1932. - S. 1-41.

Servít M., NÁdvorník J. Flechten aus der Čechoslovakei. V. Karpathorussland // Věstn. Král. Čes. Spol. Nauk., Třr. Mat.-Př́rí, 1935. - 1936. - S. 1-24.

Śliwa L., KUKWA M. Calicium pinastri (lichenized Ascomycota), a lichen species new to Poland // Polish Bot. J. $-2008 .-$ P. 187-188.

Sмith C.W. Sclerococcum Fr. (1825) / In: The Lichens of Great Britain and Ireland (Smith C.W. et al., eds). London, 2009. - P. 837.

Spribille T., Björk C.R., Ekman S., Elix J.A., Goward T., Printzen C., Tønsberg T., Wheeler T. Contributions to an epiphytic lichen flora of northwest North America: I. Eight new species from British Columbia inland rain forests // Bryologist. - 2009. - Vol. 112, N 1. - P. 109-137.

Sulma T. Materjały do flory porostów Czarnohory // Kosmos, Ser. Bot., 1932. - 1933. - R. 57, N 1-4. - P. 19-38.

SuZA J. Lišejníky Československých Karpat // Sborn. Kl. Př́rod., Brno. - 1925a. - R. 8. - S. 107-122.

SUZA J. Nástin zeměpisného rozšíření lišejníků na Moravě vzhledem k poměrům evropským // Spisy Př́rod. Fak. Masaryk. Univ. Brno. - 1925b. - Sv. 55. - S. 1-152.

SuZA J. Poznámky k epifytické floře lišejníkové doubrav u Terešvy (Podkarpatská Rus) // Sborn. Kl. Přirod., Brno. - 1925c. - R. 7. - S. 1-4.

SuZA J. Lišejníky Podkarpatské Rusi // Sborn. Př́rod. Spol., Mor. Ostrava, 1924-1925. - 1926. - R. 3. - S. 1-16.

SuZA J. Lišejníky Podkarpatské Rusi. Část druhá // Sborn. Př́rod. Spol., Mor. Ostrava, 1926-1927. - 1927. - R. 4. - S. 191-219.

Suza J. Ozeanische Züge in der epiphytischen Flechtenflora der Ostkarpathen (ČSR), bzw. Mitteleuropas // Věstn. Král. Čes. Spol. Nauk. Tř. Mat.-Př́r., 1933. - 1934. - S. 1-43.

SuZA J. Lišejníky Podkarpatské Rusi. Část třetí // Sborn. Př́rod. Spol., Mor. Ostrava. - 1936. - R. 7. - S. 49-73.

SzATALA Ö. Újabb adatok Ungmegye zúzmóflórájának ismeretéhez. II. // Magy. Bot. Lap., 1922. - 1923 - Köt. 21. - Old. 33-63.

SzATALA Ö. Adatok Magyarország zúzmóflórájának ismeretéhez. II. // Magy. Bot. Lap., 1926. - 1927a. - Köt. 25. - Old. 201-218.

SzAtala Ö. Lichenes Hungariae I. Pyrenocarpeae - Gymnocarpeae (Coniocarpineae). Magyarorszég zúzmóflórája // Folia Cryptogamica. - 1927b. - N 5. - S. 337-434.

TiBeLl L. The lichen genus Chaenotheca in the Northern Hemisphere // Symb. Bot. Upsal. - 1980. - N 23. - P. 1-69.

TIBELL L. Two new species of Calicium from Europe // Mycotaxon. - 1999. - Vol. 70. - P. 431-443.

Tibell L., Titov A.N., LisickÁ E. Calicioid lichens and fungi described by J. Nádvorník // Mycotaxon. - 2003. - Vol. 87. - P. 3-24.

TIMDAL E. The genus Hypocenomyce (Lecanorales, Lecideaceae) with special emphasis on the Norwegian and Swedish species // Nordic J. Bot. - 1984 - Vol. 4. - P. 83-108.

TøNSBERG T. The sorediate and isidiate, corticolous, crustose lichens in Norway // Sommerfeltia. - 1992. -

Vol. 14. - P. 1-331.

Tschermak-Woess E., Poelt J. Vezdaea, a peculiar lichen genus, and its phycobiont // In: Brown B.H., Hawksworth D.L., Bailey R.H. (eds) Lichenology: Progress and Problems. - Academia Press, London, 1976. - P. 89-105.

VĚZDA A. K taxonomii, rozšíření a ekologii lišejníku Belonia russula Kbr. ve stř̌ední Evropě // Přírod. Čas. Slez., Opava. - 1959. - R. 20. - S. 241-253.

VĚZDA A., PIŠÚt I. Zwei neue Arten der Flechtengattung Absconditella (lichenisierte Stictidaceae, Ostropales) in der Tschechoslowakei // Nova Hedwigia. - 1984. - B. 40. - S. 341-346.

VĚzdA A., Poelt J. Die Flechtengattung Gyalidea Lett. ex Vězda (Solorinellaceae). Eine Übersicht mit Bestimmungsschlüssel // Nova Hedwigia. - 1991. - B. 53. - S. 99-113. 
VONDrÁK J., KoCOURKovÁ J., PALICE Z., LiŠKA J. New and noteworthy lichens in the Czech Republic - genus Caloplaca. - Preslia. - 2007a. - Vol. 79. - P. 163-184.

Vondrák J., Kocourková J., Slavíková-Bayerová Š., Breuss O., Sparrius L., Hawksworth D.L. Noteworthy lichens, lichenicolous and other allied fungi recorded in Bohemian karst, Czech Republic. Bryonora. -2007b. - Vol. 40. - P. 31-40.

Vondrák J., Šoun J., Hrouzek P., Ríha P., KubÁsek J., Palice Z., Søchting U. Caloplaca subalpina and $C$. thracopontica, two new saxicolous species from the Caloplaca cerina group (Teloschistales) // Lichenologist. - 2008. - Vol. 40, N 5. - P. 375-386.

WAINIO E.A. Lichenes in Caucaso et in peninsula Taurica annis 1884-1885 ab H. Lojka et M. a Déchy collecti // Természetr. Füzetek. - 1899. - Köt. 22. - Old. 269-343.

WIRTH V. Die Flechten Baden-Württembergs I., II. - Ulmer, Stuttgart, 1995. - 1006 S.

ZAHLBRUCKNER A. Beiträge zur Flechtenflora Niederösterreichs. III. // Verh. Zool.-Bot. Gesell. Wien. - 1890. B. 40. - S. 279-290.

ZAHLBRUCKNER A. Catalogus Lichenum Universalis. 3. - Leipzig: Borntraeger, 1925. - S. 161-899.

ZalewsKa A. Collemataceae collected by Professor Tadeusz Sulma in the Czywczyn Mts. (Eastern Carpathians, Ukraine) in the years 1933 - 1936. - In: Kondratyuk S.Y., Coppins B.J. (eds): Lobarion Lichens as Indicators of the Primeval Forests of the Eastern Carpathians. M. H. Kholodny Institute of Botany, Ukrainian Phytosociological Centre. - Kiev, 1998. - P. 165-166.

ZHuRBEnKo M. Lichens and lichenicolous fungi of the northern Krasnoyarsk Territory, Central Siberia // Mycotaxon. - 1996. - Vol. 58. - P. 185-232.

Recommended to print

Received 15.03.2009 M.F. Boiko

Author's addresses:

\section{J. Vondrák}

Department of Botany,

Faculty of Science,

University of South Bohemia

Branišovská 31.

CZ-37005 České Budějovice,

Czech Republic

e-mail:j.vondrak@seznam.cz

\section{Z. Palice}

Institute of Botany,

Academy of Sciences of the Czech Republic,

CZ-252 43

Prühonice,

Czech Republic

e-mail:palice@bot.cas.cz

$\&$

Department of Botany,

Faculty of Natural Sciences, Charles University,

Benátská 2,

CZ-12801 Praha 2

Czech Republic

A. Ye. Khodosovtsev, S.V. Postoyalkin

Kherson State University

27, 40 Rokiv Zhovtnya str.

Kherson 73000

Ukraine

e-mail:khodosovtsev@ksu.ks.ua postoyalkin@yandex.ru
Aдреси авторів:

J. Vondrák

Department of Botany,

Faculty of Science,

University of South Bohemia

Branišovská 31,

CZ-37005 České Budějovice,

Czech Republic

e-mail:j.vondrak@seznam.cz

\section{Z. Palice}

Institute of Botany,

Academy of Sciences of the Czech Republic,

CZ-252 43

Prühonice,

Czech Republic

e-mail:palice@bot.cas.cz

$\&$

Department of Botany,

Faculty of Natural Sciences, Charles University,

Benátská 2,

CZ-12801 Praha 2

Czech Republic

О.С. Ходосовиев, С.В. Постоялкін

Херсонський державний університет

Вул. 40 років Жовтня, 27

Херсон, 73000

Украйна

e-mail:khodosovtsev@ksu.ks.ua postoyalkin@yandex.ru 